Karina Campos Tisovec Dufner

\title{
Intention of preserving forest remnants among landowners in the Atlantic Forest: the role of the ecological context and experiences with nature
}

Intenção de preservar remanescentes florestais entre proprietários de terra na Mata Atlântica: o papel do contexto ecológico e das experiências com a natureza

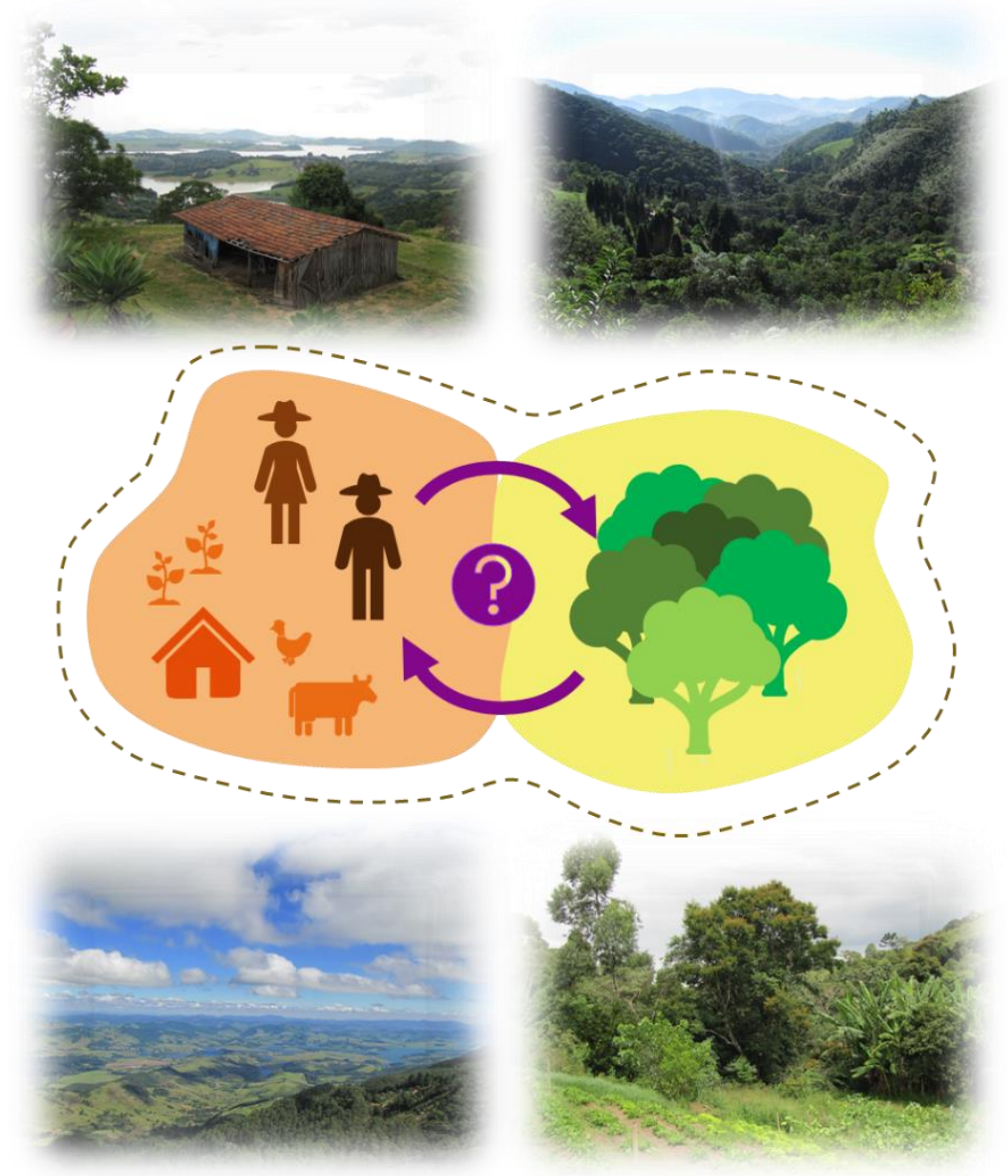

São Paulo 


$$
\begin{gathered}
\text { Universidade de São Paulo } \\
\text { Instituto de Biociências }
\end{gathered}
$$

Programa de Pós-Graduação em Ecologia

\title{
Intention of preserving forest remnants among landowners in the Atlantic Forest: the role of the ecological context and experiences with nature
}

\author{
Intenção de preservar remanescentes florestais entre \\ proprietários de terra na Mata Atlântica: o papel do contexto \\ ecológico e das experiências com a natureza
}

Karina Campos Tisovec Dufner

Dissertação apresentada ao Instituto de Biociências da Universidade de São Paulo, para a obtenção de Título de Mestre em Ciências, na Área de Ecologia.

Orientador(a): Profa. Dra. Renata Pardini

São Paulo 
Tisovec-Dufner, Karina Campos

Intention of preserving forest remnants among landowners in the Atlantic Forest: the role of the ecological context and experiences with nature

Versão em português: Intenção de preservar remanescentes florestais entre proprietários de terra na Mata Atlântica: o papel do contexto ecológico e das experiências com a natureza

$70 \mathrm{p}$.

Dissertação (Mestrado) - Instituto de Biociências da Universidade de São Paulo. Departamento de Ecologia.

1. Environmental psychology 2. Ecosystem services 3 . Socioecological systems 4. Theory of planned behavior 5 . Tropical forest I. Universidade de São Paulo. Instituto de Biociências. Departamento de Ecologia.

Versão em português: 1. Psicologia ambiental 2. Serviços ecossistêmicos 3. Sistemas socioecológicos 4. Teoria do comportamento planejado 5. Floresta tropical I. Universidade de São Paulo. Instituto de Biociências. Departamento de Ecologia.

Comissão Julgadora:

$\operatorname{Prof(a).~Dr(a).~}$

Prof(a). Dr(a).
$\operatorname{Prof}(\mathrm{a}) . \operatorname{Dr}(\mathrm{a})$.

Profa. Dra. Renata Pardini

Orientadora 


\section{Agradecimentos}

Agradeço:

À Coordenação de Aperfeiçoamento de Pessoal de Nível Superior - CAPES, pela bolsa de estudo concedida no início do meu curso de mestrado.

À Fundação de Amparo à Pesquisa do Estado de São Paulo - FAPESP, pela bolsa de estudo concedida a partir de agosto de 2018 (2016/06690-7) e pelo financiamento do Projeto Temático Interface (2013/23457-6) ao qual este trabalho é vinculado.

Ao Instituto de Biociências, aos Departamentos de Ecologia e Zoologia e ao Programa de Pós-graduação em Ecologia da Universidade de São Paulo pela infraestrutura que foi fundamental para a realização deste trabalho.

Ao Prof. Dr. Jean Paul Metzger pela coordenação do Projeto Temático Interface e por possibilitar a inclusão de mais este trabalho no projeto.

À Isabella Romitelli pela ajuda com as burocracias financeiras e durante o primeiro piloto.

À Profa Dra. Renata Pardini, minha orientadora, por todo seu esforço e incentivo a adentrar novos “don't knows". Obrigada pelo convite de trabalhar mais uma vez com você, pelos conselhos, críticas e elogios no transcorrer do trabalho, pelo exemplo de pesquisadora dedicada e competente e pela amizade ao longo desses anos.

Às professoras do comitê de acompanhamento, Carla Morsello e Emilie Coudel, pelas inúmeras sugestões e contribuições desde as fases iniciais deste trabalho, sem dúvida ele se tornou um produto muito melhor e coletivo.

Ao Lucas Teixeira, e aqui vale um super agradecimento mesmo, por todo apoio durante os meses de preparação do questionário, pilotos e coleta de dados e por cuidar sempre do nosso dindim. Obrigada pelas conversas acadêmicas e filosóficas sob céus estrelados, pelos capítulos de séries, pipocas e vinhos. Obrigada pelo companheirismo e amizade.

À todas as pessoas que se disponibilizaram a participar deste trabalho, tanto na fase do piloto, como na coleta final dos dados, sem vocês esse trabalho literalmente não seria 
possível. Obrigada pela paciência de responderem um questionário tão longo, pelas boas histórias e cafezinhos.

À Andreia Gebrael e sua família pela hospedagem calorosa durante parte do piloto.

A todos os docentes e colegas do Programa de Pós-graduação em Ecologia, especialmente do Curso de Campo e do Café Existencial, pelos aprendizados e discussões ao longo do curso, foi ótimo compartilhar esses momentos com vocês.

Aos colegas do Laboratório de Diversidade e Conservação de Mamíferos - DICOM, por todo companheirismo durante as horas de trabalho, disciplinas e filas do bandejão. Um obrigado especial à Gabriela Marin pela imensa ajuda com a teoria e implementação das análises.

À minha família, minha mãe, meu pai e meu irmão pelo apoio e incentivo que sempre me deram e por cuidarem da minha casa e dos meus gatinhos enquanto eu estava fora.

Ao meu querido marido Luiz Gustavo, simplesmente por sempre estar ao meu lado, seja gargalhando comigo ou consolando minhas lágrimas, até altas horas da madrugada. Obrigada por todo seu amor e carinho! 


\section{Table of contents}

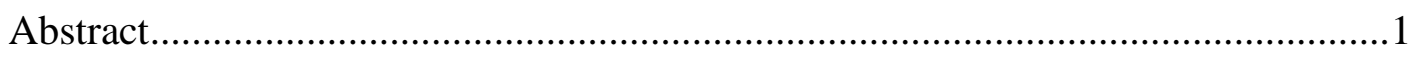

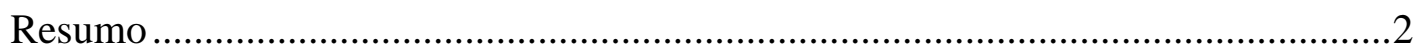

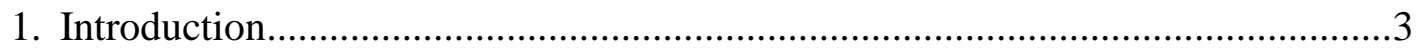

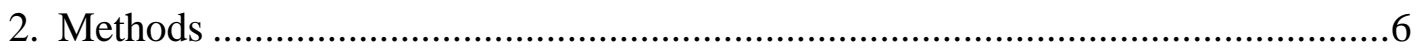

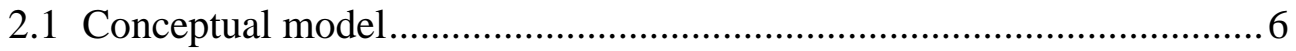

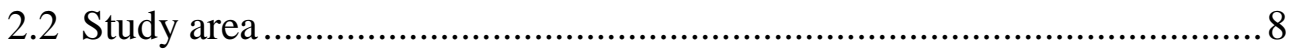

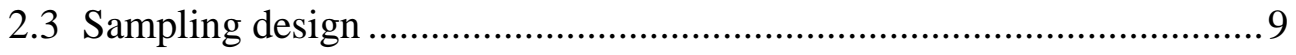

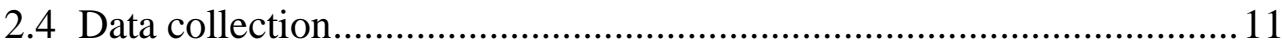

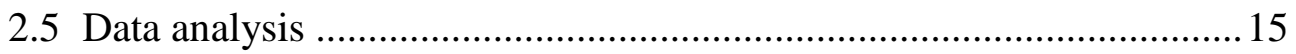

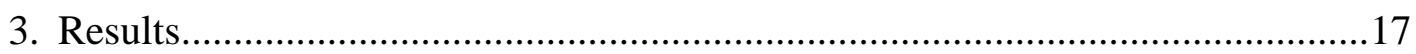

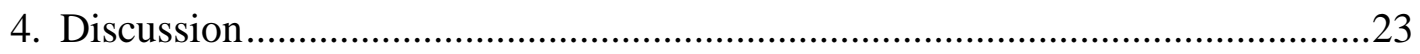

4.1 Which experiences with forest do shape the intention of preserving forest

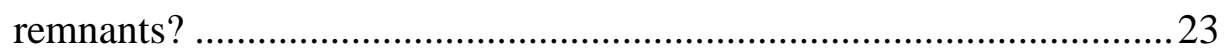

4.2 How does the ecological context influence experiences with forest and ultimately the intention to preserve it? .............................................2 27

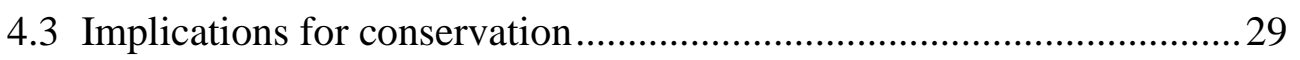

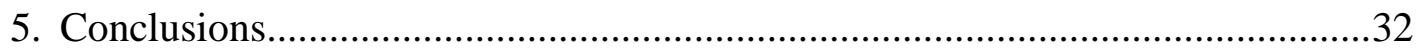

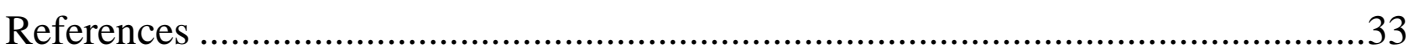

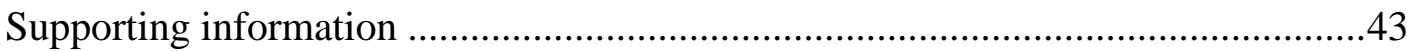

Appendix A - Selecting properties and landowners to interview ................. 43

Appendix B - Measuring experiences with nature, defining the behavior of interest and measuring the psychological constructs ............................4 45

Appendix C - Protocol applied by face-to-face interviews ........................54

Appendix D - Scales evaluation and Piecewise SEM implementation .......67 


\section{Abstract}

Unravelling the psychological processes determining landowners' support towards forest conservation is key, particularly, in developing countries, where most forest remnants are within private lands. As human-nature connections are known to shape pro-environmental behaviors, the intention of preserving forest remnants should be ultimately determined by the ecological context people live in. Here, we investigate the pathways through which the ecological context (forest cover), via experiences with nature (contact, uses and losses associated with forests), influences the psychological determinants of conservation behavior (beliefs, attitude and intention towards preserving forest remnants). We conceptualized a model based on the Reasoned Action Approach, using the ecological context and experiences with nature as background factors, and tested the model using Piecewise SEM. Data was collected through an interview-based protocol applied to 106 landowners across 13 landscapes varying in forest cover in a region in the Brazilian Atlantic Forest. Our results indicate that: (i) ecosystem services are more important than disservices for shaping intention of preserving forests, particularly those related to non-provisioning benefits; (ii) contact with forest has an indirect effect on intention, by positively influencing forest uses; (iii) people living in more forested ecological contexts have more experiences with nature, and ultimately stronger intention of preserving forests. Hence, our study suggests a dangerous positive feedback loop between deforestation and the extinction of human-nature connections. Local demands across the full range of ecosystem services, the balance between services and disservices, and the ecological context people live should be considered when developing conservation initiatives in rural areas. 


\section{Resumo}

Desvendar os processos psicológicos que determinam o apoio dos proprietários de terras à conservação das florestas é fundamental, particularmente, nos países em desenvolvimento, onde a maioria dos remanescentes florestais se encontra em áreas privadas. Como as conexões humano-natureza são conhecidas por moldar comportamentos pró-ambientais, a intenção de preservar remanescentes florestais deve ser, em última instância, determinada pelo contexto ecológico no qual as pessoas vivem. Neste trabalho, investigamos os caminhos pelos quais o contexto ecológico (cobertura florestal), através das experiências com a natureza (contato, usos e perdas associados às florestas), influencia os determinantes psicológicos do comportamento de conservação (crenças, atitude e intenção de preservar remanescentes florestais). Formulamos um modelo baseado na Abordagem da Ação Racional, usando o contexto ecológico e as experiências com a natureza como fatores de base, e o testamos através da Piecewise SEM. Os dados foram coletados através de protocolo aplicado, por meio de entrevista, a 106 proprietários de terra em 13 paisagens que variam em cobertura florestal em uma região da Mata Atlântica. Nossos resultados indicam que: (i) serviços ecossistêmicos são mais importantes que desserviços para moldar a intenção de preservar florestas, particularmente outros serviços que não os de provisão; (ii) o contato com a floresta tem um efeito indireto sobre a intenção, influenciando positivamente os usos da floresta; (iii) as pessoas que vivem em contextos ecológicos mais florestados têm mais experiências com a natureza e, assim, uma intenção mais forte de preservar as florestas. Nosso estudo, portanto, sugere um perigoso ciclo de retroalimentação positiva entre o desmatamento e a extinção das conexões humanonatureza. As demandas locais considerando toda a gama de serviços ecossistêmicos, o balanço entre serviços e desserviços e o contexto ecológico no qual as pessoas vivem devem ser considerados ao se desenvolverem iniciativas de conservação em áreas rurais. 


\section{Introduction}

In the last two decades, there has been a shift in conservation science that reflects the way human-nature relationships were conceptualized (Mace, 2014). This transition was driven by the aggravation of environmental problems and the biodiversity crisis, and by the perception that interdisciplinary efforts - beyond the traditional biologycentered initiatives - are necessary to tackle the complex, multifaceted nature of current environmental challenges (Kareiva and Marvier, 2012). Because humans are responsible for the drivers of environmental change, and conservation initiatives depend upon our choices and behavior, conservation is essentially a social phenomenon (Balmford and Cowling, 2006; Mascia et al., 2003).

Social sciences can improve policies, decision-making processes, management and outcomes of conservation initiatives through the study of social phenomena (e.g., governance, politics) and processes (e.g., communication, marketing), as well as individual attributes (e.g., values, behavior; Bennett et al., 2017). Essentially, because all social phenomena and processes are rooted in individuals, unravelling the psychological processes that determine human actions is crucial for achieving conservation goals (Bennett et al., 2017; Mascia et al., 2003) by improving support towards conservation measures (e.g., Bennett and Dearden, 2014) or compliance with conservation rules (e.g., Arias, 2015).

Understanding landowners perception of conservation issues, as a way to identify mechanisms that increase conservation support (de Snoo et al., 2013; Selinske et al., 2015), is particularly important in rural areas of developing countries because a considerable part of the remaining tropical forests is outside protected areas (MoralesHidalgo et al., 2015; Schmitt et al., 2009). These remnants are crucial for biodiversity 
conservation (e.g., Banks-Leite et al., 2014), as well as ecosystem service provision (Shvidenko et al., 2005) both at local (e.g., pest control; Librán-Embid et al., 2017) and regional/global scales (e.g., climate regulation; Canadell and Raupach, 2008) Hence, untangling the drivers of landowners' behavior towards preserving forest remnants within their lands is key to delineate strategies aiming at the maintenance of tropical biodiversity and ecosystem services.

A growing body of evidence suggests that behaviors towards nature conservation are shaped by human-nature connections that are linked to experiences with nature. For instance, experiences with nature increase the frequency of outdoors activities (Asah et al., 2012), pro-environmental attitudes and behaviors (Wells and Lekies, 2006), as well as support towards conservation (Zaradic et al., 2009; Zhang et al., 2014). In turn, recent studies suggest that these human-nature connections depend on the ecological context people live in. Individuals inhabiting rural settings often have more contact with nature than those living in urban areas (Zhang et al., 2014; Collado et al., 2015), and the distance to and amount of green spaces and trees influence people experiences with nature (Neuvonen et al., 2007; Shanahan et al., 2017). Hence, the extinction of experiences with nature (as defined by Pyle, 1993) driven by urbanization and the shift in leisure from outdoor to indoor activities (e.g. electronic devices) has been seen with great concern (Balmford and Cowling, 2006; Miller, 2005). This extinction can result in nature detachment and devaluation, leading to a dangerous feedback loop on subsequent nature experiences (Soga and Gaston, 2016).

Most evidence associating the ecological context people live, experiences with nature and attitudes or behaviors towards nature conservation, however, comes from studies considering the effects of urbanization on children (Collado et al., 2015; Zhang et al., 2014) or adult (Shanahan et al., 2017; but see Torres et al., 2016). We here aim 
to test the hypothesis that deforestation alters the ecological contexts rural people live, affecting their experience with forests and, ultimately, their intention to preserve forest remnants within their properties. We did so by conceptualizing a model based on the Reasoned Action Approach from social psychology (RAA, also known as, Theory of Planned Behavior; Fishbein and Ajzen, 2010), using the ecological context people live and their experiences with nature as background factors (Figure 1A). We focus on the Atlantic Forest of Brazil - a threatened biodiversity hotspot (Myers et al., 2000) harboring a large part of the Brazilian population and agricultural production.

Specifically, we investigate the relevant pathways through which the ecological context - represented by the amount of remaining native forest - influences beliefs, attitude, and intention of preserving forest remnants, considering as experiences with nature: (i) the degree of direct contact with forests (frequency of visits to forests), (ii) forest uses and (iii) losses or damages from forests (Figure 1A). 

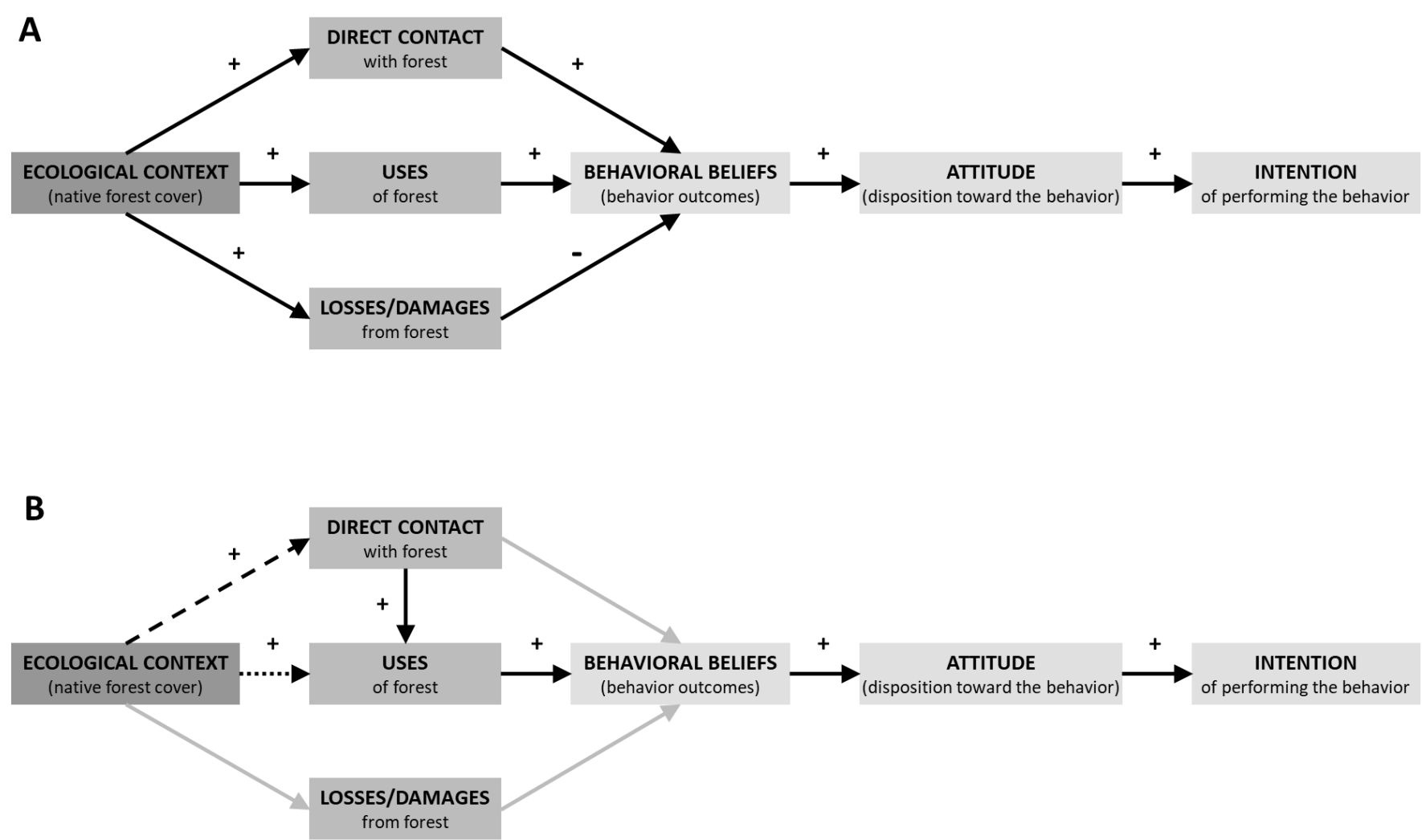

Figure 1: Conceptual model on the pathways through which the ecological context people live in influences beliefs, attitude and intention towards preserving forest remnants within private properties. A - Hypothesized initial model. B - Re-specified final model. Dark grey - ecological context variable represented by the amount of native forest, medium grey - variables of experience with nature, light grey - psychological variables associated with the behavior of preserving forest remnants. Arrows - causal links between variables. + positive effect, negative effect. In B, black arrows are significant links and grey arrows are non-significant links. The solid arrows are significant causal links considering the ecological context in any spatial scale, dashed arrow are significant causal links only considering the immediate ecological context $(0.5 \mathrm{~km}$ around households), and dotted arrows are significant causal links only considering the ecological context at larger spatial scales $(1.5$ and $2 \mathrm{~km}$ around households).

\section{Methods}

\subsection{Conceptual model}

Our conceptual model is based on the Reasoned Action Approach (RAA; Fishbein and Ajzen, 2010), which have been increasingly used to tackle people responses to environmental issues (e.g., Borges et al., 2016; de Leeuw et al., 2015). RAA assumes 
that background factors influence the psychological determinants (e.g., beliefs, attitude, intention) of a given behavior. Among background factors, sociodemographic variables are commonly considered, but previous experience is also relevant (Fishbein and Ajzen, 2010). Here we propose that the ecological context people live in and the experiences they have with nature can be conceptualized as background factors, affecting people intention to preserve forest remnants within their properties (Figure $1 \mathrm{~A})$.

We used native forest cover in the surroundings as a proxy of the ecological context where people live (Figure 1A). The amount of native forest not only is related to the proximity and size of forest ecosystems available in the landscape, but also determines the diversity and integrity of biological communities in the Atlantic Forest (Banks-Leite et al., 2014), and thus should affect ecosystem services and disservices (e.g., Librán-Embid et al., 2017). We expect these aspects of forest ecosystem proximity, size, integrity and functioning - influence the opportunities and ways people experience nature (Figure 1A). Specifically, we expect that forest cover increases: (i) the direct contact people have with forest by increasing proximity or access to forests, (ii) the uses people make from forests by increasing ecosystem service provision, and (iii) certain types of losses and damages, such as those caused by wildlife, by increasing wildlife abundance and movement (Soto-Shoender and Giuliano, 2011).

Direct contact with forest, forest uses and losses and damages from forests are then conceptualized as human-nature experiences, which are known to influence proenvironmental behaviors (e.g., Wells and Lekies, 2006; Zaradic et al., 2009, Figure 1A). Previous studies have shown that people having more contact and uses from forest increase the value assigned to forests (e.g., Torres et al., 2016). In contrast, negative experiences (i.e., losses and damages from forest), such as those resulting from 
conflicts with wildlife, are known to reduce the positive perceptions towards nature (Campbell-Smith et al., 2010; Mir et al., 2015).

The final part of the model concerns the pathways linking the psychological constructs based on the RAA (Fishbein and Ajzen, 2010; Figure 1A). According to this model, the primary psychological elements leading to a behavior (e.g., preserving forest within properties) are the beliefs people hold towards that action. Individuals differ widely in their beliefs, as they are not innate but acquired through learning processes and previous experiences (the background factors). In RAA, behavioral beliefs represent what people believe will happen (i.e. specific outcomes related to benefits or harms/disadvantages) when the behavior is performed. The behavioral beliefs are, in turn, the antecedents of personal attitude, (i.e., how favorable or unfavorable a person is in relation to the behavior). Thus, the stronger the beliefs on the benefits compared to beliefs on harms/disadvantages associated with the behavior, the more favorable the attitude towards the behavior is. Lastly, attitude is one of the determinants of the intention of performing a given behavior (i.e., the readiness or the perceived subjective probability of performing that behavior), so that the more favorable a person is towards the behavior, the greater is the intention of performing it. RAA considers that, along with attitude, subjective social norms and perceived behavior control determine the intention of performing a behaviour. However, we did not consider these other antecedents of intention in our model as they are not supposed to be clearly linked to the ecological context people live.

\subsection{Study area}

The 3,000-km² study region encompasses extensively and densely populated (5.5 \pm 4.9 households $\mathrm{km}^{2}$ ) rural areas of ten municipalities in the Atlantic Plateau of São 
Paulo, Brazil (Figure 2A-B), where nearly 50,000 people live (IBGE, 2011). The size of rural properties in the region is largely heterogeneous, varying from $>1$ to 4095 ha (mean \pm SD: $28 \pm 104 \mathrm{ha}$ ), and the main farming activities are dairy cattle raising and eucalyptus forestry.

Altitude varies from $700 \mathrm{~m}$ to $1700 \mathrm{~m}$ and climate is classified as humid subtropical, cwa according to Köppen, with a rainy summer and a dry winter (Miranda et al., 2016). Originally, the region was covered by dense montane ombrophylous Atlantic Forest, now reduced to several remnants varying in size and regeneration stages. Most of these remnants are inside private rural properties and are essential for biodiversity conservation as they connect large tracks of Atlantic Forest in the Cantareira-Mantiqueira complex. Additionally, the remaining forest fragments within the study region are crucial for the Cantareira reservoir system, which supplies water for the São Paulo Metropolitan Area (Coutinho et al., 2015), where more than 21 million people live (EMPLASA, 2018).

\subsection{Sampling design}

We adopted a three-step, hierarchical sampling design. We first selected landscapes within the study region that varied in the proportion of native forest cover, and then selected rural private properties within these landscapes and individuals to interview within the households of these properties.

Landscapes - We selected 13 landscapes of 3-km radius (2830 ha) maximizing difference in native forest cover $(10-50 \%$, Figure $2 \mathrm{~B})$, to ensure variation in the ecological context, but controlling for factors associated with agricultural potential. Landscapes were then restricted in relation to altitude (800 to $1200 \mathrm{~m}$ ), soil type (either ferric red latosol or argisol) and land-use (mainly cattle pastures and, secondly, 
eucalyptus plantations). We also avoided major interstate highways, water reservoirs and large urban areas.

Properties - To select properties within the 13 landscapes, we used the information from the Rural Environmental Registry (Cadastro Ambiental Rural - CAR). CAR is mandatory for owners of rural properties destined to agriculture (INCRA, 2010). Using a forest cover map and the limits of properties declared in CAR, we calculated the amount of native forest in each property. We excluded properties that had no houses or that the main house was located outside the study landscape (checked with Google Earth), that overlapped more than one study landscape or encompassed less than 1 ha of native forest (to restrict to properties harboring forests of some conservation value). This procedure resulted in a set of 301 properties visited subsequently (Appendix A).

Participants - By visiting all 301 pre-selected properties, we checked if the landowner self-declared as the responsible for deciding how to manage the property inhabited the property and was of age, if so, he/she was invited to participate in the study (Appendix A). Among the 301 properties, 129 landowners matched the criteria above, and 106 of them accepted participating in the study and were subsequently interviewed (Figure 2C, Appendix A). 
A

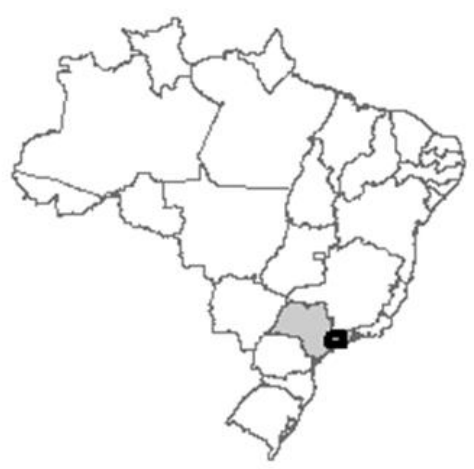

C
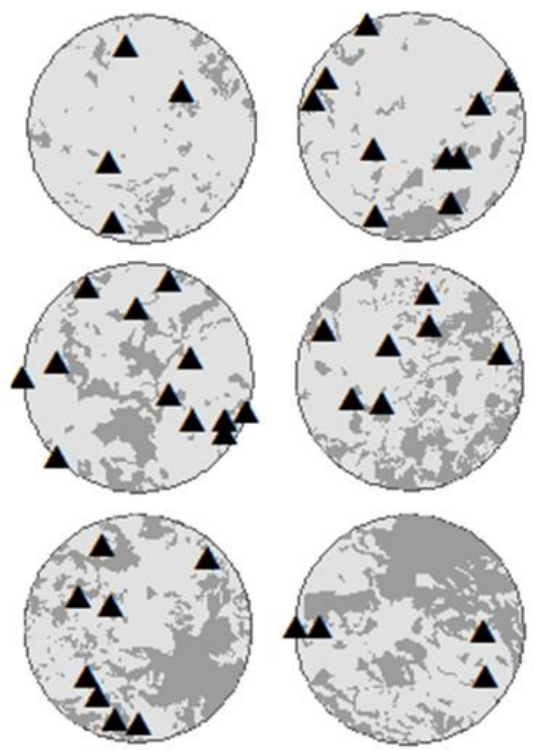

B
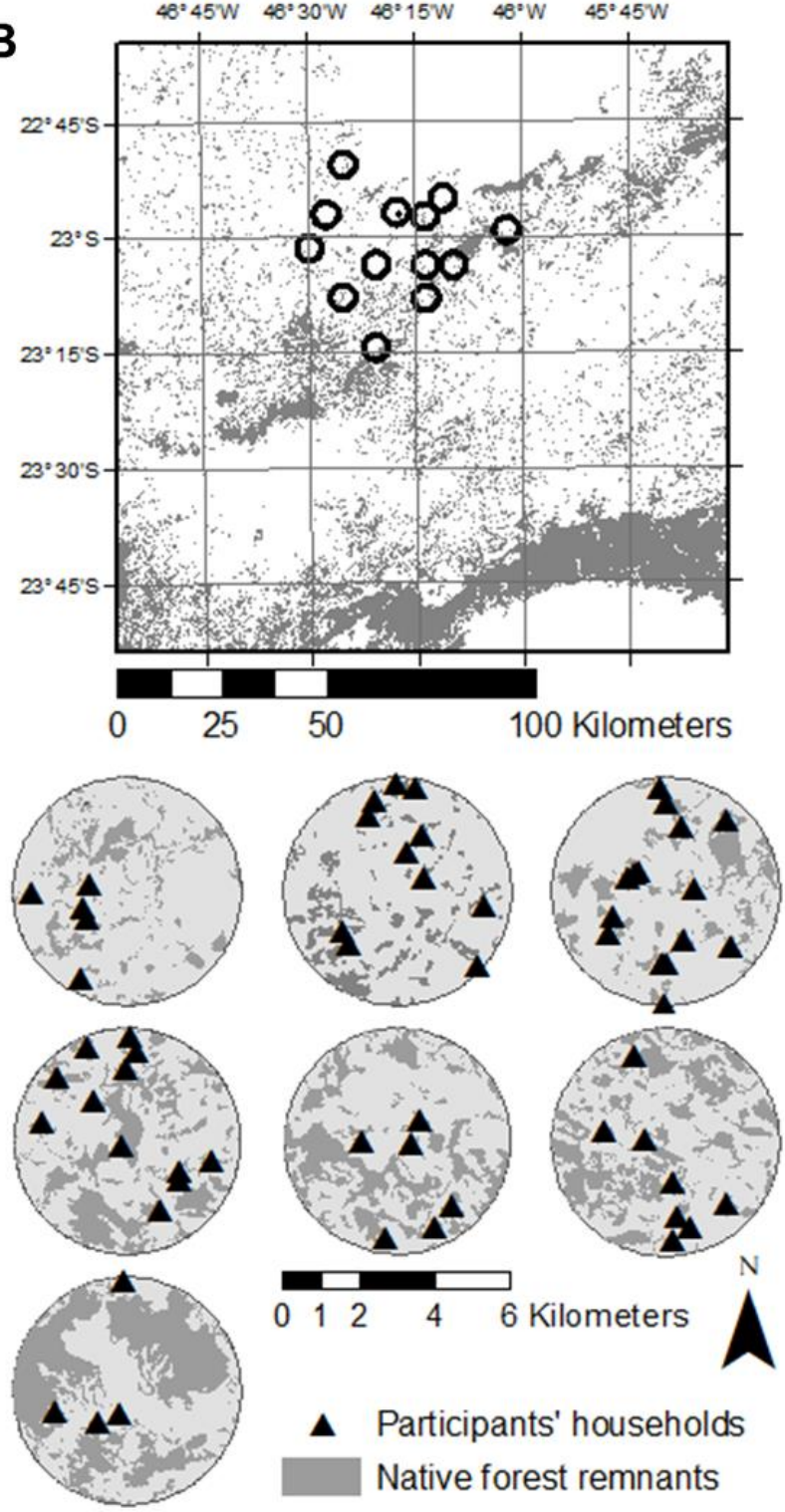

$\begin{array}{lllll}0 & 1 & 2 & 4 & 6\end{array}$ Kilometers

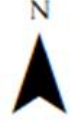

A Participants' households Native forest remnants

Figure 2: Study region, study landscapes and the location of participants' households. A - São Paulo State in Brazil and the study region. B - Atlantic Forest remnants and the study landscapes. C - Location of participants' households within the study landscapes, ordered in ascending percentage of forest cover.

\subsection{Data collection}

Ecological context - To assess the ecological context, we calculated native forest cover around the households of the 106 participants. We considered four radii $(0.5$, $1.0,1.5$ and $2.0 \mathrm{~km}$ ) around the households to account for possible differences in the 
spatial scale relevant to determine distinct types of experiences (in particular, direct contact with forest may be associated with forest cover at smaller spatial scales than forest uses or losses from forests). The variation in forest cover was similar among the four radii, varying between $0-58 \%, 4-53 \%, 4-57 \%$ and $5-55 \%$ at $0.5,1.0,1.5$ and 2.0 $\mathrm{km}$ radius, respectively.

Using a structured protocol applied via face-to-face interviews, we quantified the variables related to experiences with nature, the psychological variables, and additional variables to describe the sampled population. Prior to data collection, we tested the protocol, adjusting the language and response format to avoid misinterpretations and increase accuracy.

Experiences with forest - The three variables - direct contact with forest, forest uses and losses and damages from forest - were measured as frequencies. To quantify the direct contact with forests, we considered the number of days the individual went to the forest in the month prior to the interview, even if for a short visit (i.e., less than 30 minutes). To quantify forest uses and the losses/damages from forest, we considered the last six months prior to the interview and adopted a visual unipolar scale with seven categories (1-never to 7-always, Appendix B). Both variables were multi-item indices, describing either the types of forest uses or of losses/damages from forest. These items were based on the salient behavioral beliefs (see below), elicited in the studied population, associated with either the benefits or the harms/disadvantages of preserving forests, respectively (Appendix B). For the index of forest uses, items included both direct consumptive and non-consumptive uses, excluding indirect uses (e.g., water or air purification; for which the frequency of use cannot be accurately measured) and non-use benefits (e.g., legacy gratification). For the index of losses form forests, items included all types of losses associated with the salient beliefs. To 
calculate the indices of use and losses/damages, we summed the values across the 11 and six items, respectively.

Beliefs, attitude and intention - To estimate the behavioral beliefs, attitude and intention within the RAA framework, the behavior under investigation should be clearly defined (Fishbein and Ajzen, 2010; Appendix B). From pilot interviews to identify the actions people commonly do to preserve forests in their properties and how they refer to forest preservation in their daily language, we defined the behavior of interest as: "Taking care of the forest in the property for the next five years" (Appendix B). The action of "taking care of the property forest" was explained to participants as encompassing one or more of the following specific behaviors: (i) fencing and/or guarding the forest, (ii) removing garbage from the forest, and avoiding (iii) the use of fire to clear the land, (iv) the construction of forest trails or roads, and/or (v) clearings and thinning the forest (Appendix B). Therefore, our intention was to measure the effort to actively maintain forest integrity and thus the behavior of interest comprises more than keeping native forest within the property, as required by the Brazilian Forest Code that regulates the protection of native vegetation in private lands. According to this law, landowners in the Atlantic Forest should keep native forests in $20 \%$ of their properties (the Legal Reserve; Reserva Legal - RL) and in fragile areas (e.g., river banks, hilltops, steep slopes) known as Permanent Protection Areas (Área de Proteção Permanente - APP) (“Federal Law 12.727," 2012; Soares-Filho et al., 2014).

Behavioral beliefs are related to perceived behavioral outcomes (e.g., taking care of the forest provides us with a better climate) and should be elicited from the population of interest to account for the actual local salient beliefs (Fishbein and Ajzen, 2010), which we did during a pilot study (Appendix B). The index of behavioral beliefs 
then included 17 items associated with benefits, and six items associated with harms/disadvantages, of performing the behavior of interest. According to Pascual et al. (2010) classification, the 17 items related to benefits were a posteriori divided into eight associated with consumptive direct uses, three with non-consumptive direct uses, three with indirect uses, and three with non-use benefits (Appendix B). Using the expectancy-value model (Fishbein and Ajzen, 2010), the behavioral belief index was calculated as the sum of the product between the strength (i.e., the subjective probability of that specific outcome - belief - resulting from the behavior of interest) and the evaluation (i.e., how essential or severe the individual considers that specific outcome to be) across all 23 items (i.e., salient beliefs). The product of the six salient beliefs associated with harms/disadvantages was multiplied by -1 , so that its contribution to the belief index was negative. Participants responded to items concerning belief strength and evaluation by choosing between seven categories of a visual unipolar scale (Appendix B).

We measured attitude with a traditional semantic differential scale (Osgood et al., 1978) composed of six pairs of adjectives as the scale endings (i.e., six items). Three adjectives were related to an instrumental aspect, while three to an experiential aspect, of the behavior "taking care of forest". For each of these six items (e.g., how useless/useful do you think it is to take care of the forest), participants responded using a visual bipolar scale with seven categories $(-3$ to +3$)$, and we summed up the values across the six items (Appendix B).

To measure intention, we used a Likert scale composed of eight items, each corresponding to a sentence (i.e., statement) expressing different motivational states (e.g., you want to take care of the forest), being four favorable and four unfavorable towards performing the behavior of interest. Participants gave their level of agreement 
to each item using a visual unipolar scale with seven categories, and the intention scale was calculated as the sum across all eight items (Appendix B).

Additional variables - To characterize the population, we asked participants their sex, age, and schooling level (number of completed school years). We also asked the context (rural, urban or both) (i) where the current productive activity is conducted (e.g., in their own properties or in the city) and (ii) where they spent their childhood (until 10 years old).

Interviewing - Interviews were conducted by two researchers (KCTD and LMCT) from March to August 2017. To minimize interviewer bias, both researchers were present during the first 30 interviews to standardize their way of talking and acting. At the interview onset, researchers delivered to participants a summary folder containing the project idea and contact information, and a consent term informing the voluntary and privacy aspects of the study. The protocol (Appendix C) was approved by the Research Ethics Committee from the Brazilian National Commission for Research Ethics (CAAE $n^{\circ}$ 61720916.0.0000.5464 in Plataforma Brasil).

\subsection{Data analysis}

Scale evaluation - In psychometrics, scale items are developed to measure the same underlying construct, and a high inter-item correlation is expected (Streiner, 2003; Widhiarso and Ravand, 2014). We used three analyses - the Cronbach's alpha coefficient $(\alpha)$, the omega hierarchical coefficient $\left(\omega_{\mathrm{h}}\right)$ and Confirmatory Factor Analysis (CFA) and its associated fit measures - to test the reliability and validity of the scales for measuring attitude and intention of taking care of forest. All these analyses indicated that both scales were reliable and satisfactorily measured a single construct (Appendix D). Differently from scales, there is no need to evaluate the multi- 
item variables representing indices (Bollen and Bauldry, 2011; Hennessy et al., 2012), such as the indices of behavioral beliefs, forest uses or losses/damages from forests (i.e., their items were not meant to measure the same underlying construct, but rather to represent distinct aspects of either beliefs, uses or losses).

Testing the conceptual model - To evaluate our initial conceptual model (Figure 1A), we adopted a recently-developed analytical procedure, the Piecewise Structural Equation Modeling (Piecewise SEM; Lefcheck, 2016a). Compared to traditional SEM, the Piecewise SEM requires smaller sample size, does not assume a multinormal distribution (i.e., allowing to model different variables with their appropriate distributions) and allows the incorporation of mixed-effects, necessary given the hierarchical nature of our sampling design. To implement the analyses, we used the piecewiseSEM package in $\mathrm{R}$ (Lefcheck, 2016b), first investigating which distribution best fitted each of the response variables (Appendix D), and considering the 13 study landscapes as a random variable.

In Piecewise SEM, the comparison of the data to the hypothesised model is made using an alternative to the chi-square test for goodness-of-fit, the Fisher's C statistic (Lefcheck, 2016a). If the corresponding P-value is greater than 0.05, the data supports the hypothesised model. If the fit is poor (i.e., P-value $\leq 0.05$ ), the next step is to respecify the model, including missing paths shown as important by the Piecewise analysis. After obtaining a model supported by the data, the relevant (i.e., significant) causal paths can be identified.

Fisher's C statistic can be used to calculate the Akaike's Information Criterion (AIC) or AIC corrected for small samples (AICc) (Shipley, 2013). This allows comparing the plausibility of different models that vary only in the independent 
variables (i.e., variables that are not affected by any of the variables in the model, such as forest cover in our model). We then run the initial conceptual model (Figure 1A) four times, each using one of the four ecological context measures (i.e., native forest cover in the surroundings at four spatial scales) and assessed model fit. After including the conceptually plausible missing paths indicated as important by the analysis, starting with the most significant, and achieving a model supported by the data, we compared the models with the four ecological context variables through AICc. Although a $\Delta \mathrm{AIC} \leq 2$ indicates equally plausible models, only when $\Delta \mathrm{AIC}>10$ a model can be discarded as having no essential empirical support (Burnham and Anderson, 2002). We then evaluated the relevant pathways through which the ecological context affects behavioral beliefs, attitude and intention towards the behavior of interest using the P-value for each path in each of the models with the four ecological context variables.

\section{Results}

The size of the rural properties owned by the participants varied considerably, from 2 to 309 ha, although most were smaller than 20 ha (52\%). The area of native forest inside those properties also varied substantially, from 1 to 193 ha, with the majority (59\%) smaller than 5 ha. Among the 106 landowners, most were men (75\%). Age ranged from 23 to 82 years, but most interviewees were older (44\% older than 60 years; $15 \%$ younger than 40 years). The general schooling level was low to medium, varying from no school attendance (3\%) up to 21 years of study (i.e., participants with graduate study degree), with 51\% having completed less than five years of study. Most participants $(79 \%)$ spent their working hours in farming activities in their properties (e.g., taking care of their crops and livestock), with only 9\% working in urban 
occupations (e.g., store employees). Moreover, most participants were raised in rural contexts $(74 \%)$, whereas only $18 \%$ in urban areas and $8 \%$ spent their childhood in both rural and urban areas.

The number of visits to forest in the previous month - a measure of the direct contact with forests - averaged 2.75 visits, with $42 \%$ of participants having visited the forest at least once (Table 1). The indices of forest use and losses from forest indicate that, on average, uses are far more frequent than damages (Table 1, Figure 3). Participants had, on average, positive beliefs, attitude and intention of taking care of forests within their properties (Table 1).

Table 1: Mean, median and standard deviation among the 106 participants of the values for the indices/scales measuring experiences with forest and psychological constructs towards preserving forest remnants within their properties.

\begin{tabular}{cccccc}
\hline & Variable & Mean $( \pm$ SD) & Median & Min $^{\mathbf{a}}$ & Max $^{\mathbf{b}}$ \\
\hline \multirow{2}{*}{ Experiences } & Direct contact & $2.75(6.29)$ & 0 & 0 & 30 \\
with forest & Uses & $37.2(9.8)$ & 37 & $11(11)$ & $60(77)$ \\
& Losses/damages & $11.01(4.65)$ & 10 & $6(6)$ & $28(42)$ \\
\hline \multirow{3}{*}{ Psychological } & Behavioral beliefs & $493.6(149)$ & 527.5 & $-240(-277)$ & $+795(+827)$ \\
& Attitude & $11.87(6.47)$ & 14 & $-18(-18)$ & $+18(+18)$ \\
& Intention & $44.75(9.26)$ & 47 & $11(8)$ & $56(56)$ \\
\hline
\end{tabular}

${ }^{a}$ Minimum value observed and minimum possible value (in parenthesis)

${ }^{\mathrm{b}}$ Maximum value observed and maximum possible value (in parenthesis)

For both belief strength and evaluation, responses varied strongly across items. Among belief items indicating the benefits from forests, both those associated with non-consumptive (e.g., appreciating plants and animals) and indirect uses (e.g., climate regulation), together with those associated with non-use benefits (e.g., legacy gratification) were perceived as more likely and essential, having the highest correlation with attitude (from 0.35 to 0.66 , Figure 3A-B). Among belief items associated with consumptive uses, water was the most important, with over half of the participants considering that they would be more assured of having spring water for 
their household if they took care of their forest (i.e. belief strength) and that this water is essential (i.e. belief evaluation). In contrast, belief items indicating harms/disadvantages resulting from preserving forests were perceived as quite unlikely, with the problems related to hazards and attacks towards humans, livestock and crops being considered the worst (Figure 3A-B). Beliefs related to positive (benefits) and negative (harms/disadvantages) outcomes of preserving forest remnants also differed in their degree of correlation to attitude towards preserving forest, with a higher correlation for the positive items (mean $\pm \mathrm{SD}: 0.37 \pm 0.18$ ) than for negative items (mean \pm SD: $0.30 \pm 0.06$, Figure 3B).

In general, there was a strong congruence between what participants believed were the outcomes of preserving forest remnants within their properties (i.e., the responses to beliefs items) and what they experienced (i.e., the responses to items of the indices of both forest uses and losses or damages from forest; Figure 3). Water for people and livestock, as well as feeling joy and peaceful were the most frequent uses, whereas the most common loss was related to wild animals damaging crops (Figure 3C-D). 

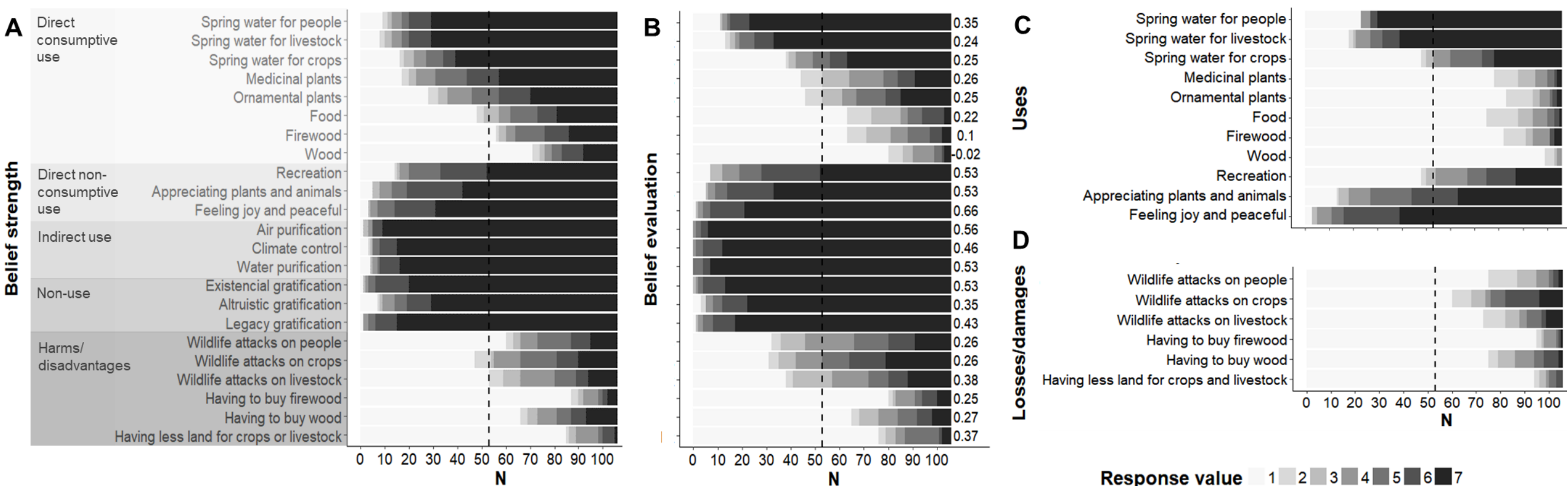

Response value $\quad 1 \square 2 \square 3 \square 4 \square 5 \square 6 \square 7$

Figure 3: Responses to items of indices for measuring beliefs towards preserving forest remnants, forest uses and losses/damages from forests among the 106 participants. Responses were measured with a 7-category visual unipolar scale. A - Belief strength measured as outcome probability (1-no way to 7-surely). Non-use beliefs represent different types of personal gratification (for knowing that nature exists and that it can be enjoyed by others or by future generations). The last three beliefs associated with disadvantages are related to restrictions in the use of firewood, wood or land caused by forest preservation. B - Belief evaluation measured as how essential (for benefits) or severe (for harms/disadvantages) the outcome is (1-nothing to 7-very). The values at the right indicate the correlation of each belief (the product of the strength and evaluation) and the attitude scale. $\mathrm{C}$ - Forest uses, both consumptive and non-consumptive, measured as frequencies (1-never to 7-always). D - Losses or damages from forest measured as frequencies (1-never to 7-always). Dashed vertical line - half of the participants $(\mathrm{N}=53)$. 
Conceptual model - Based on the Fisher's C statistic, our initial conceptual model on the pathways through which the ecological context rural people live in influences their beliefs, attitude and intention of preserving forest remnants within their properties (Figure 1A) presented low fit irrespective of the scale we measured the ecological context $(\mathrm{C}>97.3, \mathrm{df}=26, \mathrm{p}<0.05$, Table 2$)$. The analysis suggested the same three missing paths in all cases, which varied considerably in their significance level (pvalue; Table 2). We re-specified the model including only the most significant missing link - between direct contact with forests and forest uses, which is conceptually plausible (having a greater contact with forest would give people more opportunities to use forests). As after including this link the model was supported by the data for all spatial scales we measured the ecological context $(\mathrm{C}<26, \mathrm{df}=24, \mathrm{p}>0.33$, Table 2 , Figure 1B), we did not included the remaining missing paths.

Despite the similar values of AICc of the re-specified models (within 4 of $\triangle \mathrm{AICc}$; Table 2), the significant pathways linking the ecological context and the intention of preserving forest remnants differed depending on the spatial scale the ecological context was measured (Figure 1B). The links between (i) direct contact with forest and forest uses, (ii) forest uses and behavioral beliefs, (iii) behavioral beliefs and attitude, and (iv) attitude and intention were significant and positive in all models. In contrast, the causal link between ecological context and direct contact with forests was significant and positive only when considering the immediate ecological context $(0.5$ $\mathrm{km}$ ), whereas the causal link between ecological context and forest uses was significant and positive only when considering the ecological context at larger spatial scales (1.5 and $2 \mathrm{~km}$, Figure 1B). 
Table 2: Piecewise SEM results for the conceptual models on the pathways through which the ecological context rural people live in influences beliefs, attitude and intention of preserving forest remnants within their properties.

\begin{tabular}{|c|c|c|c|c|c|c|c|c|c|c|}
\hline \multirow{2}{*}{$\begin{array}{c}\text { Conceptual } \\
\text { Model }\end{array}$} & \multirow{2}{*}{$\begin{array}{l}\text { Ecological context } \\
\text { - forest cover } \\
\text { around household } \\
(\mathbf{k m})\end{array}$} & \multirow{2}{*}{$\begin{array}{c}\text { Fisher's } \\
\text { C }\end{array}$} & \multirow{2}{*}{$\begin{array}{l}\text { Degrees of } \\
\text { freedom }\end{array}$} & \multirow[t]{2}{*}{ P-value $^{a}$} & \multirow[t]{2}{*}{$\mathrm{AICc}^{\mathrm{b}}$} & \multirow[t]{2}{*}{$\triangle \mathrm{AICc}$} & \multirow[t]{2}{*}{$\mathbf{K}^{\mathbf{d}}$} & \multicolumn{3}{|c|}{ Missing path P-values } \\
\hline & & & & & & & & $\begin{array}{l}\text { Direct contact } \\
\text { - Uses }\end{array}$ & $\begin{array}{l}\text { Uses - } \\
\text { Intention }\end{array}$ & $\begin{array}{c}\text { Losses/damages } \\
\text { Uses }\end{array}$ \\
\hline & 0.5 & 97.30 & 26 & $<0.05$ & - & - & 25 & $<0.0001$ & 0.005 & 0.04 \\
\hline Initial & 1 & 97.50 & 26 & $<0.05$ & - & - & 25 & $<0.0001$ & 0.005 & 0.04 \\
\hline \multirow[t]{3}{*}{ Model } & 1.5 & 99.63 & 26 & $<0.05$ & - & - & 25 & $<0.0001$ & 0.005 & 0.04 \\
\hline & 2 & 101.26 & 26 & $<0.05$ & - & - & 25 & $<0.0001$ & 0.005 & 0.03 \\
\hline & 0.5 & 23.55 & 24 & 0.49 & 93.32 & 0.00 & 26 & - & - & - \\
\hline \multirow{3}{*}{$\begin{array}{l}\text { Final } \\
\text { Model }\end{array}$} & 1 & 23.82 & 24 & 0.47 & 93.59 & 0.27 & 26 & - & - & - \\
\hline & 1.5 & 25.12 & 24 & 0.40 & 94.89 & 1.57 & 26 & - & - & - \\
\hline & 2 & 26.48 & 24 & 0.33 & 96.25 & 2.93 & 26 & - & - & - \\
\hline
\end{tabular}

${ }^{\text {a }} \mathrm{P}$-value $>0.05$ indicates a good fit

b Akaike's Information Criterion corrected for small samples

${ }^{\mathrm{c}}$ Difference in AICc value compared to the first-ranked model $(0.5 \mathrm{~km})$

${ }^{\mathrm{d}}$ Number of parameters 


\section{Discussion}

Our results highlight the importance of the ecological context rural people live in, via experiences with nature, for the formation of behavioral beliefs, attitude and intention towards preserving forest remnants. To our knowledge, these results are novel, as they expand the findings of previous studies conducted in urban contexts (e.g., Wells and Lekies, 2006; Zaradic et al., 2009), to suggest that deforestation in rural areas lead to the extinction of experiences with nature and to weak intention of forest conservation. In the following paragraphs, we first discuss which experiences shape the intention of preserving forests. We then focus on how these experiences are influenced by the ecological context people live. We end up by discussing four implications of our results to forest conservation in private lands.

\subsection{Which experiences with forest do shape the intention of preserving forest remnants?}

Experiences with nature can be both positive or negative. Indeed, the same ecosystem can bring both services and disservices, because despite the system itself is value-free, humans assign different values to system properties - either attributes or functions - determining the relative importance of services and disservices (Vaz et al., 2017). Our results suggest that ecosystem services are far more important than disservices for shaping attitude and intention of preserving forests. Four lines of evidence support this statement. First, forest uses, unlike losses from forests, significantly (and positively) affected the beliefs on the outcomes of preserving forest remnants. Second, people reported higher frequencies of forest uses than losses from forests. Third, among the studied population, the number of salient positive beliefs 
(associated with benefits provided by forests, $n=17$ ) were much higher than the number of salient negative beliefs (associated with harms/disadvantages suffered from forests, $\mathrm{n}=6$ ). Lastly, most items related to positive beliefs were ranked higher, and were more correlated with attitude towards preserving forest remnants, than those related to negative beliefs.

Although there is growing evidence that an ecological system can be simultaneously perceived as advantageous and disadvantageous (e.g., Ango et al., 2014; Rasmussen et al., 2017), few studies explored how the balance between these perceptions influence the determinants of behaviors towards nature conservation. In one of the few studies doing so, Dorresteijn and collaborators (2017) also observed that people valued services more than disservices in a rural area in Ethiopia where people were more dependent on forest products and suffered a higher intensity of disservices than in our study region. However, they did not find that this balance between perceived advantages and disadvantages influence the attitude towards forests.

In addition to the importance of ecosystem services (i.e., forest uses) compared to disservices (i.e., losses/damages from forest) in shaping beliefs, attitude and intention of preserving forest, we found that, across different ecosystem services, those related to non-provisioning benefits are of foremost importance. People believed that the outcomes of preserving forests related to direct non-consumptive uses (e.g., appreciating plants and animals), indirect uses (e.g., air purification) as well as nonuse benefits (e.g., legacy gratification) were more likely and essential than outcomes related to most provisioning services (e.g., medicinal plants). Moreover, while reporting on forest uses, they considered they received these services more frequently than most provisioning services. This corroborates other studies showing that people 
recognize and value forests for their non-provisioning benefits (Dorresteijn et al., 2017; Torres et al., 2016), and these benefits should thus influence people proenvironmental behaviors and support to conservation initiatives.

Consumptive uses related to provisioning services can nonetheless be important for the livelihoods of local communities, especially wood fuels and bushmeat (Angelsen et al., 2014), an exceptionally relevant resource to rural people throughout the tropics (Milner-Gulland and Bennett, 2003). In contrast, these provisioning services were not important in our study region - located near several urban centers probably because these resources are currently rare (e.g., bushmeat) and/or because people can easily purchase substitutes (e.g., gas stoves, industrialized medicines, marketed meet). The most important provisioning service - both in terms of beliefs towards preserving forests and frequency of use - was water for human and livestock consumption. The high perceived value of water may be explained by a recent drastic drought that caused a severe water crisis in the region (Coutinho et al., 2015).

Among disservices, those perceived as most relevant were related to wildlife impacts, as observed elsewhere (Dorresteijn et al., 2017). The management and mitigation of human-wildlife conflicts are considered essential for the conservation of many threatened species (e.g., Seoraj-Pillai and Pillay, 2016), and there is growing awareness that conflict mitigation depends on understanding attitude and tolerance towards wildlife (Decker et al., 2012). Although damage caused by wildlife, particularly to livestock and crops, negatively affect attitude and tolerance towards wildlife (Kansky et al., 2014; Zimmermann et al., 2005), intangible costs, such as fear, appear to have stronger effects (Kansky et al., 2016). Hence, as losses from wildlife attacks may not be the most important factor, the lack of association between disservices and attitude or intention of preserving forest remnants is no surprise. 
However, we should highlight that these losses may affect tolerance towards wildlife even though they did not affect the intention of preserving forests, something we did not evaluate (but see Teixeira, 2018). Moreover, in our study region, landowners perceived these losses as unlikely and irrelevant, and happening at low frequencies, which is not surprising considering that the native fauna is relatively impoverished in Atlantic Forest remnants (Cullen et al., 2000; Negrão and Valladares-Pádua, 2006) and large carnivores such as jaguars (Panthera onca) are nowadays absent in the study region (Ribeiro, 2016). Indeed, based on the salient beliefs elicited among the studied populations, the animals perceived as causing damage in the region are mainly exotic invasive species, such as wild boars (Sus scrofa).

In contrast to the positive direct effects that forest uses had on the beliefs towards this ecosystem and, ultimately, on the intention to preserve it, experiencing forests through direct contact (i.e., visiting forest) was far less relevant, having only an indirect effect on beliefs through positively affecting forest uses. This relatively lower relevance may partially relate to how we measured contact and uses. Visits are just one of several ways people can have contact with nature, which includes watching and contemplating forest animals and plants at a distance (i.e., not necessary being inside a forest). This type of contact was incorporated in our measure of forest uses (e.g., appreciating forest plants and animals, feeling joy and peaceful by contemplating forest). Furthermore, some forest uses common in the study region depend on visiting forests (e.g., recreation), while the main reason for visiting forests was taking care of water springs (an activity related to the most relevant consumptive use from forests water). Thus, direct contact via visits to forests is strongly associated with using forests (as indicated by the strong significant relationship between them in the Piecewise SEM analysis). Additionally, part of the effect of contact with forest on beliefs towards 
forests was incorporated by us as a type of use received from forests. Direct contact with nature, however, has been shown to positively contribute to the formation of values towards nature. For instance, number of visits to forests positively influenced forest values in a context where visits are much more frequent, because people are more dependent on forests for their livelihoods (Torres et al., 2016). Direct contact also influenced environmental attitude and behavior in youngsters participating in environmental education programs (Duerden and Witt, 2010), as well as the affective attitude towards biodiversity and its conservation in children from urban environments (Soga et al., 2016).

\subsection{How does the ecological context influence experiences with forest and ultimately the intention to preserve it?}

Our results provide evidence that the ecological context people live, and especially the amount of remaining forest at the landscape, positively influences experiences with nature (both forest uses and direct contact with forest), ultimately affecting the intention of preserving forests. The effect of the ecological context on the experiences with nature, however, depended on the spatial scale for which we measured forest cover. Only when considering smaller scales (i.e., $0.5 \mathrm{~km}$ ), we observed a significant positive effect of the ecological context on direct contact with forest. Given that we estimated direct contact as the number forest visits, it is not surprising that people who visit forests more often are those inhabiting houses immediately surrounded by a higher amount of forest. In contrast, the positive effect on forest uses was significant only at larger spatial scales (i.e., 1.5 and $2 \mathrm{~km}$ ). Again, this is expected given the variety of uses/benefits we measured, some of which depend on the maintenance of forest at broad spatial scales (e.g., hydrological cycle regulation; Shvidenko et al., 
2005). As those broad scales exceed the size of most properties in the region, several forest uses depend on conserving forests in neighboring properties, as observed elsewhere (Dorresteijn et al., 2017), indicating the necessity of coordinated conservation efforts among individuals living in the same landscape (Zhang et al., 2007). Similar to the relevance of considering landscape characteristics at different spatial scales in biodiversity studies (e.g., Gonthier et al., 2014; Kleijn et al., 2011), our results highlight the importance of multi-scale assessments of the ecological context in studies focusing on human behavior.

Several studies discuss the importance of the social, political and economic contexts to human valuation process (e.g., Shackleton et al., 2016; Vaz et al., 2017). A smaller number of studies, however, consider the role that the spatial-ecological context (e.g., altitude, forest and resource proximity) has on the perception of ecosystem services and disservices (Ango et al., 2014; Rasmussen et al., 2017); yet, they did not link these experiences with nature to attitude or intention towards nature (but see Dorresteijn et al., 2017). Hence, our results are novel, and expand the findings related to urbanization that suggest the ecological context - urban versus rural (Collado et al., 2015; Zhang et al., 2014) or the amount of tree cover (Shanahan et al., 2017) influence the willingness to conserve, pro-environmental behaviors and/or humannature connections. Therefore, as urbanization, deforestation in rural areas may also impact experiences with nature ultimately affecting behavior towards nature.

Thus, our results suggest the possibility of a dangerous positive feedback loop between deforestation and the extinction of human-nature connections, particularly via decreasing the use and valuation of ecosystem services, leading to lower intention of preserving forests and potentially to further deforestation. This idea has been previously proposed in general terms by Soga and Gaston (2016). Yet to directly test 
the potential of such feedback loops, we still need long term longitudinal studies that take into account how patterns of ecosystem service use, beliefs, attitude an intention towards nature change throughout lifespan (i.e., intragenerational) and how they are transmitted across generations (i.e., intergenerational; Grønhøj and Thøgersen, 2009). Moreover, we should highlight that, although the effect of the ecological context on the intention of preserving forest was significant and positive, even in the most deforested contexts people still had, on average, neutral to positive beliefs, attitude and intention of preserving forest.

Finally, the effects we observed of the ecological context on the intention of preserving forests open up new intriguing research questions. For instance, whether there are thresholds in beliefs, attitude and intention of pro-environmental behaviors as the loss of native vegetation progresses, alike those found for populations and ecological communities (Banks-Leite et al., 2014). In case these psychological thresholds do exist, whether they are congruent with ecological thresholds. Finally, whether the feedback relating native vegetation cover and intention of preserving native vegetation is strong enough to lead to alternative stable states and critical transitions in rural landscapes (sensus Scheffer, 2009). These questions may have the potential to further tighten the bonds between the ecological and social sciences in achieving conservation goals.

\subsection{Implications for conservation}

First, our results suggest the key role the use of natural resources, together with non-use benefits provided by ecosystems, may have to the success of conservation initiatives. Until the eighties, conservation biology was focused on isolating humans from nature through the implementation of restricted-use protected areas (Mace, 2014; 
Soulé, 1985), many times leading to the displacement of local communities and social conflicts (Agrawal and Redford, 2009). Restricted-use PAs still are one of the main strategies to biodiversity conservation and, undoubtedly, are crucial, albeit not sufficient (Kareiva and Marvier, 2012). In private lands, in particular, beyond nonvoluntary strategies, such as those represented by laws as the Brazilian Forest Code, voluntary mechanisms that rely on the factors affecting landowners' willingness to comply to laws and to preserve forest integrity (besides keeping forest in their lands) are of foremost importance. Using forest and receiving non-use benefits from it are key experiences determining how people value this ecosystem and should be considered to improve the success of conservation efforts.

Second, conservation initiatives should consider the perceptions of local communities regarding both ecosystem services and disservices. Ecosystem service approach to conservation has grown considerably and a large effort has been put to identify and map ecosystem services at large scales (Dickson et al., 2014; Li and Fang, 2014; Martínez-Harms and Balvanera, 2012). Nevertheless, the approach often disregard the existence of ecosystem disservices, and the trade-offs between services and disservices (Hicks et al., 2015; Small et al., 2017). Moreover, the perception of services and disservices varies across distinct contexts (Shackleton et al., 2016; Vaz et al., 2017; Zhang et al., 2007). Hence, beyond mapping the provision of services at large scales, local initiatives incorporating specificities concerning the demand for ecosystem services as determined by how local people value different services and disservices, is crucial to increase the chance of engaging local people into conservation actions. For instance, in our study region, conservation initiatives focusing on water provision should have a great potential for promoting voluntary actions from landowners to preserve forest remnants. 
Third, accounting for all types of ecosystems services, including both use and nonuse benefits, is key. Ecosystems provide a variety of services, often creating trade-offs for different stakeholders, and to be comprehensive, decision processes such as prioritizing one benefit over the other, should not ignore less tangible benefits (Daniel et al., 2012). Often the most valued ecosystem services do not have market values, as those related to non-consumptive uses (also known as cultural services), indirect services and to non-use benefits, making them more difficult to monetize (Pascual et al., 2010; Small et al., 2017). Hence, developing techniques to account for ecosystem services related to indirect uses, recreation or spiritual uses (e.g., Daniel et al., 2012; de Groot et al., 2010), among others, is of foremost importance.

Lastly, it is essential to incorporate the ecological context when planning environmental policies and ecosystem management in rural areas. In forested landscapes, initiatives focusing on sustainable forest uses and non-use benefits are more likely to succeed because human-nature connections should be stronger. In contrast, in areas where native forest cover has been largely reduced, human-nature connections tend to be impaired, because ecosystem services themselves have been lost, so reestablishing this lost connection should be the initial priority (as proposed in Abson et al., 2017; Miller, 2005; Stokes, 2006). Although re-connection strategies, such as increasing opportunities to interact with nature (e.g., providing more green spaces) or increasing a positive orientation towards nature (e.g., outdoor playing during childhood) (Soga and Gaston, 2016), have been proposed for urban environments, comparable strategies focusing on rural landowners are still to be developed and tested. 


\section{Conclusions}

- Human-nature experiences are important for shaping support towards conservation initiatives. Particularly, we showed the key role of ecosystem services for shaping beliefs, attitude and intention of landowners to preserve forest within their properties, compared to the effects of the direct contact with forests or the losses and damages associated with these ecosystems. Unraveling how landowners interact with and value forests can help to develop conservation strategies based on voluntary behaviors such as maintaining forest integrity.

- Ecosystems can bring both services and disservices to people, and the perception of these two types of experiences are context dependent. To increase local people willingness to conserve, it is crucial to incorporate context specific demands on ecosystem services (for example, the great importance people attributed to water), beyond mapping services at broad scales.

- In our study, ecosystem services had a far more important effect on landowners' intention to preserve forests than disservices, including those related to nonprovisioning services, such as, direct non-consumptive uses, indirect uses and nonuse benefits. Hence, efforts to develop existing and creating new techniques that can account for less tangible ecosystem services are necessary to enable better and more comprehensive decision-making processes.

- Finally, we showed that the ecological context people live in, particularly the amount of forest cover, can influence human-nature experiences, ultimately affecting their support towards forest conservation. Hence, like urbanization, deforestation may lead to the extinction of human-nature experiences, fostering a dangerous feedback of nature depreciation. While in forested landscapes 
sustainable forest uses and non-use benefits are likely to foster support to conservation, in deforested areas strategies to re-establish human-nature connections may be needed and should be developed in the context of landowners in rural environments.

\section{References}

Abson, D.J., Fischer, J., Leventon, J., Newig, J., Schomerus, T., Vilsmaier, U., von Wehrden, H., Abernethy, P., Ives, C.D., Jager, N.W., Lang, D.J., 2017. Leverage points for sustainability transformation. Ambio 46, 30-39. https://doi.org/10.1007/s13280-016-0800-y

Agrawal, A., Redford, K., 2009. Conservation and displacement: An overview. Conserv. Soc. 7, 1. https://doi.org/10.4103/0972-4923.54790

Angelsen, A., Jagger, P., Babigumira, R., Belcher, B., Hogarth, N.J., Bauch, S., Börner, J., Smith-Hall, C., Wunder, S., 2014. Environmental Income and Rural Livelihoods: A Global-Comparative Analysis. World Dev. 64, S12-S28. https://doi.org/10.1016/j.worlddev.2014.03.006

Ango, T.G., Börjeson, L., Senbeta, F., Hylander, K., 2014. Balancing Ecosystem Services and Disservices: Smallholder Farmers\&\#8217; Use and Management of Forest and Trees in an Agricultural Landscape in Southwestern Ethiopia. Ecol. Soc. 19. https://doi.org/10.5751/ES-06279-190130

Arias, A., 2015. Understanding and managing compliance in the nature conservation $\begin{array}{llll}\text { context. J. } & \text { Environ. }\end{array}$ https://doi.org/10.1016/j.jenvman.2015.02.013

Asah, S.T., Bengston, D.N., Westphal, L.M., 2012. The Influence of Childhood: Operational Pathways to Adulthood Participation in Nature-Based Activities. Environ. Behav. 44, 545-569. https://doi.org/10.1177/0013916510397757 
Balmford, A., Cowling, R.M., 2006. Fusion or Failure? The Future of Conservation Biology. Conserv. Biol. 20, 692-695. https://doi.org/10.1111/j.15231739.2006.00434.x

Banks-Leite, C., Pardini, R., Tambosi, L.R., Pearse, W.D., Bueno, A.A., Bruscagin, R.T., Condez, T.H., Dixo, M., Igari, A.T., Martensen, A.C., Metzger, J.P., 2014. Using ecological thresholds to evaluate the costs and benefits of setasides in a biodiversity hotspot. Science 345, 1041-1045. https://doi.org/10.1126/science. 1255768

Bennett, N.J., Dearden, P., 2014. Why local people do not support conservation: Community perceptions of marine protected area livelihood impacts, governance and management in Thailand. Mar. Policy 44, 107-116. https://doi.org/10.1016/j.marpol.2013.08.017

Bennett, N.J., Roth, R., Klain, S.C., Chan, K.M.A., Clark, D.A., Cullman, G., Epstein, G., Nelson, M.P., Stedman, R., Teel, T.L., Thomas, R.E.W., Wyborn, C., Curran, D., Greenberg, A., Sandlos, J., Veríssimo, D., 2017. Mainstreaming the social sciences in conservation: Mainstreaming the Social Sciences. Conserv. Biol. 31, 56-66. https://doi.org/10.1111/cobi.12788

Bollen, K.A., Bauldry, S., 2011. Three Cs in measurement models: Causal indicators, composite indicators, and covariates. Psychol. Methods 16, 265-284. https://doi.org/10.1037/a0024448

Borges, J.A.R., Tauer, L.W., Lansink, A.G.J.M.O., 2016. Using the theory of planned behavior to identify key beliefs underlying Brazilian cattle farmers' intention to use improved natural grassland: A MIMIC modelling approach. Land Use Policy 55, 193-203. https://doi.org/10.1016/j.landusepol.2016.04.004

Burnham, K.P., Anderson, D.R., 2002. Model selection and multimodel inference: a practical information-theoretic approach, 2nd ed. ed. Springer, New York.

Campbell-Smith, G., Simanjorang, H.V.P., Leader-Williams, N., Linkie, M., 2010. Local attitudes and perceptions toward crop-raiding by orangutans (Pongo abelii) and other nonhuman primates in northern Sumatra, Indonesia. Am. J. Primatol. 72, 866-876. https://doi.org/10.1002/ajp.20822 
Canadell, J.G., Raupach, M.R., 2008. Managing Forests for Climate Change Mitigation. Science 320, 1456-1457. https://doi.org/10.1126/science.1155458

Collado, S., Corraliza, J.A., Staats, H., Ruiz, M., 2015. Effect of frequency and mode of contact with nature on children's self-reported ecological behaviors. J. Environ. Psychol. 41, 65-73. https://doi.org/10.1016/j.jenvp.2014.11.001

Coutinho, R.M., Kraenkel, R.A., Prado, P.I., 2015. Catastrophic Regime Shift in Water Reservoirs and São Paulo Water Supply Crisis. PLOS ONE 10, e0138278. https://doi.org/10.1371/journal.pone.0138278

Cullen, L., Bodmer, R.E., Valladares Pádua, C., 2000. Effects of hunting in habitat fragments of the Atlantic forests, Brazil. Biol. Conserv. 95, 49-56. https://doi.org/10.1016/S0006-3207(00)00011-2

Daniel, T.C., Muhar, A., Arnberger, A., Aznar, O., Boyd, J.W., Chan, K.M.A., Costanza, R., Elmqvist, T., Flint, C.G., Gobster, P.H., Gret-Regamey, A., Lave, R., Muhar, S., Penker, M., Ribe, R.G., Schauppenlehner, T., Sikor, T., Soloviy, I., Spierenburg, M., Taczanowska, K., Tam, J., von der Dunk, A., 2012. Contributions of cultural services to the ecosystem services agenda. Proc. Natl. Acad. Sci. $\quad$ 109, 8812-8819. https://doi.org/10.1073/pnas.1114773109

de Groot, R.S., Alkemade, R., Braat, L., Hein, L., Willemen, L., 2010. Challenges in integrating the concept of ecosystem services and values in landscape planning, management and decision making. Ecol. Complex. 7, 260-272. https://doi.org/10.1016/j.ecocom.2009.10.006

de Leeuw, A., Valois, P., Ajzen, I., Schmidt, P., 2015. Using the theory of planned behavior to identify key beliefs underlying pro-environmental behavior in high-school students: Implications for educational interventions. J. Environ. Psychol. 42, 128-138. https://doi.org/10.1016/j.jenvp.2015.03.005

de Snoo, G.R., Herzon, I., Staats, H., Burton, R.J.F., Schindler, S., van Dijk, J., Lokhorst, A.M., Bullock, J.M., Lobley, M., Wrbka, T., Schwarz, G., Musters, C.J.M., 2013. Toward effective nature conservation on farmland: making farmers matter: Toward effective nature conservation on farmland. Conserv. Lett. 6, 66-72. https://doi.org/10.1111/j.1755-263X.2012.00296.x 
Decker, D.J., Riley, S.J., Siemer, W.F. (Eds.), 2012. Human dimensions of wildlife management, 2nd ed. ed. Johns Hopkins University Press, Baltimore.

Dickson, B., Blaney, R., Miles, L., Regan, E., van Soesbergen, A., Väänänen, E., Blyth, S., Harfoot, M., Martin, C., McOwen, C., Newbold, T., van Bochove, J.-W., 2014. Towards a global map of natural capital: key ecosystem assets. United Nations Environment Programme, Nairobi, Kenya.

Dorresteijn, I., Schultner, J., Collier, N.F., Hylander, K., Senbeta, F., Fischer, J., 2017. Disaggregating ecosystem services and disservices in the cultural landscapes of southwestern Ethiopia: a study of rural perceptions. Landsc. Ecol. 32, 21512165. https://doi.org/10.1007/s10980-017-0552-5

Duerden, M.D., Witt, P.A., 2010. The impact of direct and indirect experiences on the development of environmental knowledge, attitudes, and behavior. J. Environ. Psychol. 30, 379-392. https://doi.org/10.1016/j.jenvp.2010.03.007

EMPLASA, E.P. de P.M., 2018. Região Metropolitana de São Paulo [WWW Document]. EMPLASA. URL https://www.emplasa.sp.gov.br/RMSP (accessed 4.18.18).

Federal Law 12.727 [WWW Document], 2012. URL www.planalto. gov.br/ccivil_03/_Ato2011-2014/2012/Lei/L12727.htm (accessed 3.31.18).

Fishbein, M., Ajzen, I., 2010. Predicting and changing behavior: the reasoned action approach. Psychology Press, New York.

Gonthier, D.J., Ennis, K.K., Farinas, S., Hsieh, H.-Y., Iverson, A.L., Batary, P., Rudolphi, J., Tscharntke, T., Cardinale, B.J., Perfecto, I., 2014. Biodiversity conservation in agriculture requires a multi-scale approach. Proc. R. Soc. B Biol. Sci. 281, 20141358-20141358. https://doi.org/10.1098/rspb.2014.1358

Grønhøj, A., Thøgersen, J., 2009. Like father, like son? Intergenerational transmission of values, attitudes, and behaviours in the environmental domain. J. Environ. Psychol. 29, 414-421. https://doi.org/10.1016/j.jenvp.2009.05.002

Hennessy, M., Bleakley, A., Fishbein, M., 2012. Measurement Models for Reasoned Action Theory. Ann. Am. Acad. Pol. Soc. Sci. 640, 42-57. https://doi.org/10.1177/0002716211424709 
Hicks, C.C., Cinner, J.E., Stoeckl, N., McClanahan, T.R., 2015. Linking ecosystem services and human-values theory: Ecosystem Services and Human Values. Conserv. Biol. 29, 1471-1480. https://doi.org/10.1111/cobi.12550

IBGE, I.B. de G. e E. (Ed.), 2011. Sinopse do censo demográfico, 2010. IBGE, Rio de Janeiro.

INCRA, 2010. Incra | O que é Imóvel Rural nos termos da legislação agrária ? [WWW Document]. URL http://www.incra.gov.br/o-que-e-imovel-rural-nos-termosda-legislacao-agraria (accessed 1.26.18).

Kansky, R., Kidd, M., Knight, A.T., 2016. A wildlife tolerance model and case study for understanding human wildlife conflicts. Biol. Conserv. 201, 137-145. https://doi.org/10.1016/j.biocon.2016.07.002

Kansky, R., Kidd, M., Knight, A.T., 2014. Meta-Analysis of Attitudes toward Damage-Causing Mammalian Wildlife: Attitudes to Damage-Causing Wildlife. Conserv. Biol. 28, 924-938. https://doi.org/10.1111/cobi.12275

Kareiva, P., Marvier, M., 2012. What Is Conservation Science? BioScience 62, $962-$ 969. https://doi.org/10.1525/bio.2012.62.11.5

Kleijn, D., Rundlöf, M., Scheper, J., Smith, H.G., Tscharntke, T., 2011. Does conservation on farmland contribute to halting the biodiversity decline? Trends Ecol. Evol. 26, 474-481. https://doi.org/10.1016/j.tree.2011.05.009

Lefcheck, J.S., 2016a. PiecewiseSEM: Piecewise structural equation modelling in R for ecology, evolution, and systematics. Methods Ecol. Evol. 7, 573-579. https://doi.org/10.1111/2041-210X.12512

Lefcheck, J.S., 2016b. Piecewise Structural Equation Modeling.

Li, G., Fang, C., 2014. Global mapping and estimation of ecosystem services values and gross domestic product: A spatially explicit integration of national 'green GDP' accounting. Ecol. Indic. 46, 293-314. https://doi.org/10.1016/j.ecolind.2014.05.020

Librán-Embid, F., De Coster, G., Metzger, J.P., 2017. Effects of bird and bat exclusion on coffee pest control at multiple spatial scales. Landsc. Ecol. 32, 1907-1920. https://doi.org/10.1007/s10980-017-0555-2 
Mace, G.M., 2014. Whose conservation? Science 345, 1558-1560. https://doi.org/10.1126/science.1254704

Martínez-Harms, M.J., Balvanera, P., 2012. Methods for mapping ecosystem service supply: a review. Int. J. Biodivers. Sci. Ecosyst. Serv. Manag. 8, 17-25. https://doi.org/10.1080/21513732.2012.663792

Mascia, M.B., Brosius, J Peter, Dobson, Tracy A, Forbes, Bruce C, Horowitz, Leah, McKean, Margaret A, Turner, Nancy A, 2003. Conservation and the Social Sciences. Conserv. Biol. 17, 649-650.

Miller, J.R., 2005. Biodiversity conservation and the extinction of experience. Trends Ecol. Evol. 20, 430-434. https://doi.org/10.1016/j.tree.2005.05.013

Milner-Gulland, E.J., Bennett, E.L., 2003. Wild meat: the bigger picture. Trends Ecol. Evol. 18, 351-357. https://doi.org/10.1016/S0169-5347(03)00123-X

Mir, Z.R., Noor, A., Habib, B., Veeraswami, G.G., 2015. Attitudes of Local People Toward Wildlife Conservation: A Case Study From the Kashmir Valley. Mt. Res. Dev. 35, 392-400. https://doi.org/10.1659/MRD-JOURNAL-D-1500030.1

Miranda, M.J., Pinto, H.S., Júnior, J.Z., Fagundes, R.M., Fonsechi, D.B., Calve, L., Pellegrino, G.Q., 2016. A classificação climática de Koeppen para o Estado de São Paulo [WWW Document]. URL https://Www.cpa.unicamp.br/outrasinformacoes/clima-dos-municipios-paulistas.html (accessed 3.24.16).

Morales-Hidalgo, D., Oswalt, S.N., Somanathan, E., 2015. Status and trends in global primary forest, protected areas, and areas designated for conservation of biodiversity from the Global Forest Resources Assessment 2015. For. Ecol. Manag. 352, 68-77. https://doi.org/10.1016/j.foreco.2015.06.011

Myers, N., Mittermeier, R.A., Mittermeier, C.G., da Fonseca, G.A.B., Kent, J., 2000. Biodiversity hotspots for conservation priorities. Nature 403, 853-858. https://doi.org/10.1038/35002501

Negrão, M. de F.F., Valladares-Pádua, C., 2006. Registros de mamíferos de maior porte na Reserva Florestal do Morro Grande, São Paulo. Biota Neotropica 6. https://doi.org/10.1590/S1676-06032006000200006 
Neuvonen, M., Sievänen, T., Tönnes, S., Koskela, T., 2007. Access to green areas and the frequency of visits - A case study in Helsinki. Urban For. Urban Green. 6, 235-247. https://doi.org/10.1016/j.ufug.2007.05.003

Osgood, C.E., Suci, G.J., Tannenbaum, P.H., 1978. The measurement of meaning. University of Illinois Press, Urbana-Champaign.

Pascual, U., Muradian, R., Brander, L., Gómez-Baggethun, E., Martín-López, B., Verma, M., Armsworth, P., Christie, M., Cornelissen, H., Eppink, F., Farley, J., Loomis, J., Pearson, L., Perrings, C., Polasky, S., 2010. The economics of valuing ecosystem services and biodiversity, in: The Economics of Ecosystems and Biodiversity (TEEB): The Ecological and Economic Foundations. Earthscan, London and Washington.

Pyle, R.M., 1993. The thunder tree: lessons from an urban wildland. Houghton Mifflin, Boston.

Rasmussen, L.V., Christensen, A.E., Danielsen, F., Dawson, N., Martin, A., Mertz, O., Sikor, T., Thongmanivong, S., Xaydongvanh, P., 2017. From food to pest: Conversion factors determine switches between ecosystem services and disservices. Ambio 46, 173-183. https://doi.org/10.1007/s13280-016-0813-6

Ribeiro, F.S., 2016. Disturbance or propagule pressure? Unraveling the drivers of the invasion by free-ranging dogs in Atlantic forest.

Scheffer, M., 2009. Critical transitions in nature and society, Princeton studies in complexity. Princeton University Press, Princeton, N.J.

Schmitt, C.B., Belokurov, A., Besançon, C., Boisrobert, L., Burgess, N.D., Campbell, A., Coad, L., Fish, L., Gliddon, D., Humphries, K., Kapos, V., Loucks, C., Lysenko, I., Miles, L., Mills, C., Minnemeyer, S., Pistorius, T., Ravilious, C., Steininger, M., Winkel, G., 2009. Global Ecological Forest Classification and Forest Protected Area Gap Analysis. Analyses and recommendations in view of the $10 \%$ target for forest protection under the Convention on Biological Diversity (CBD) (No. 2nd revised edition). Freiburg University Press, Freiburg, Germany.

Selinske, M.J., Coetzee, J., Purnell, K., Knight, A.T., 2015. Understanding the Motivations, Satisfaction, and Retention of Landowners in Private Land 
Conservation Programs: Landowner commitment to conservation. Conserv. Lett. 8, 282-289. https://doi.org/10.1111/conl.12154

Seoraj-Pillai, N., Pillay, N., 2016. A Meta-Analysis of Human-Wildlife Conflict: South African and Global Perspectives. Sustainability 9, 34. https://doi.org/10.3390/su9010034

Shackleton, C.M., Ruwanza, S., Sanni, G.K.S., Bennett, S., Lacy, P.D., Modipa, R., Mtati, N., Sachikonye, M., Thondhlana, G., 2016. Unpacking Pandora's Box: Understanding and Categorising Ecosystem Disservices for Environmental Management and Human Wellbeing. Ecosystems 19, 587-600. https://doi.org/10.1007/s10021-015-9952-z

Shanahan, D.F., Cox, D.T.C., Fuller, R.A., Hancock, S., Lin, B.B., Anderson, K., Bush, R., Gaston, K.J., 2017. Variation in experiences of nature across gradients of tree cover in compact and sprawling cities. Landsc. Urban Plan. 157, 231-238. https://doi.org/10.1016/j.landurbplan.2016.07.004

Shipley, B., 2013. The AIC model selection method applied to path analytic models compared using a d-separation test. Ecology 94, 560-564. https://doi.org/10.1890/12-0976.1

Shvidenko, A., Barber, C.V., Persson, R., Gonzalez, P., Hassan, R., Lakyda, P., McCallum, I., Nilsson, S., Pulhin, J., Rosenburg, B. van, Scholes, B., Angeles, M. de los, Sastry, C., 2005. Forest and Woodland Systems, in: Ecosystems and Human Wellbeing: Current State and Trends. Island Press, pp. 585-621.

Small, N., Munday, M., Durance, I., 2017. The challenge of valuing ecosystem services that have no material benefits. Glob. Environ. Change 44, 57-67. https://doi.org/10.1016/j.gloenvcha.2017.03.005

Soares-Filho, B., Rajao, R., Macedo, M., Carneiro, A., Costa, W., Coe, M., Rodrigues, H., Alencar, A., 2014. Cracking Brazil's Forest Code. Science 344, 363-364. https://doi.org/10.1126/science.1246663

Soga, M., Gaston, K., Yamaura, Y., Kurisu, K., Hanaki, K., 2016. Both Direct and Vicarious Experiences of Nature Affect Children's Willingness to Conserve Biodiversity. Int. J. Environ. Res. Public. Health 13, 529. https://doi.org/10.3390/ijerph13060529 
Soga, M., Gaston, K.J., 2016. Extinction of experience: the loss of human-nature interactions. Front. Ecol. Environ. 14, 94-101. https://doi.org/10.1002/fee.1225

Soto-Shoender, J.R., Giuliano, W.M., 2011. Predation on livestock by large carnivores in the tropical lowlands of Guatemala. Oryx 45, 561-568. https://doi.org/10.1017/S0030605310001845

Soulé, M.E., 1985. What Is Conservation Biology? BioScience 35, 727-734. https://doi.org/10.2307/1310054

Stokes, D.L., 2006. Conservators of Experience. BioScience 56, 7. https://doi.org/10.1641/0006-3568(2006)056[0007:COE]2.0.CO;2

Streiner, D.L., 2003. Being Inconsistent About Consistency: When Coefficient Alpha Does and Doesn't Matter. J. Pers. Assess. 80, 217-222. https://doi.org/10.1207/S15327752JPA8003_01

Teixeira, L.M.C., 2018. Tolerance towards wildlife in the Atlantic forest: an empirical test across different ecological contexts and mammal species.

Torres, P.C., Morsello, C., Parry, L., Pardini, R., 2016. Who Cares about Forests and Why? Individual Values Attributed to Forests in a Post-Frontier Region in $\begin{array}{lllll}\text { Amazonia. } & \text { PLOS }\end{array}$ https://doi.org/10.1371/journal.pone.0167691

Vaz, A.S., Kueffer, C., Kull, C.A., Richardson, D.M., Vicente, J.R., Kühn, I., Schröter, M., Hauck, J., Bonn, A., Honrado, J.P., 2017. Integrating ecosystem services and disservices: insights from plant invasions. Ecosyst. Serv. 23, 94-107. https://doi.org/10.1016/j.ecoser.2016.11.017

Wells, N.M., Lekies, K.S., 2006. Nature and the Life Course: Pathways from Childhood Nature Experiences to Adult Environmentalism. Child. Youth Environ. 16, 1-24.

Widhiarso, W., Ravand, H., 2014. Estimating reliability coefficient for multidimensional measures: A pedagogical illustration. Rev. Psychol. 21, 111121. 
Zaradic, P.A., Pergams, O.R.W., Kareiva, P., 2009. The Impact of Nature Experience on Willingness to Support Conservation. PLoS ONE 4, e7367. https://doi.org/10.1371/journal.pone.0007367

Zhang, W., Goodale, E., Chen, J., 2014. How contact with nature affects children's biophilia, biophobia and conservation attitude in China. Biol. Conserv. 177, 109-116. https://doi.org/10.1016/j.biocon.2014.06.011

Zhang, W., Ricketts, T.H., Kremen, C., Carney, K., Swinton, S.M., 2007. Ecosystem services and dis-services to agriculture. Ecol. Econ. 64, 253-260. https://doi.org/10.1016/j.ecolecon.2007.02.024

Zimmermann, A., Walpole, M.J., Leader-Williams, N., 2005. Cattle ranchers' attitudes to conflicts with jaguar Panthera onca in the Pantanal of Brazil. Oryx 39, 406. https://doi.org/10.1017/S0030605305000992 


\section{Supporting information}

\section{Appendix A - Selecting properties and landowners to interview}

Table A1 shows information on the 13 study landscapes, quantifying the number

of properties and landowners, among the 1123 declared in the Rural Environmental Registry (Cadastro Ambiental Rural - CAR), that were excluded from the study for different reasons. 
Table A1: Selection of properties and participants within the 13 study landscapes.

\begin{tabular}{|c|c|c|c|c|c|c|c|c|c|c|c|c|c|}
\hline \multirow[b]{2}{*}{ Landscape } & \multirow[b]{2}{*}{ FC } & \multirow[b]{2}{*}{ RER } & \multirow[b]{2}{*}{ Total } & \multicolumn{4}{|c|}{ Reasons for excluding properties } & \multirow[b]{2}{*}{ Visited } & \multicolumn{4}{|c|}{ Reasons for not interviewing the landowner } & \multirow[b]{2}{*}{ Interview } \\
\hline & & & & $\begin{array}{c}\text { No } \\
\text { household }\end{array}$ & $\begin{array}{c}\text { Household } \\
\text { outside }\end{array}$ & $\begin{array}{c}\text { Two } \\
\text { Landscapes }\end{array}$ & $\begin{array}{c}\text { Forest }<1 \\
\text { ha }\end{array}$ & & $\begin{array}{c}\text { No } \\
\text { resident }\end{array}$ & Tenant & Caretaker & $\begin{array}{c}\text { Refuse/ } \\
\text { inaccessible }\end{array}$ & \\
\hline 1 & 10.11 & 72.33 & 107 & 8 & 4 & 0 & 71 & 24 & 11 & 0 & 3 & 2 & 8 \\
\hline 2 & 13.74 & 71.52 & 100 & 11 & 4 & 0 & 51 & 34 & 13 & 3 & 6 & 0 & 12 \\
\hline 3 & 14.75 & 54.90 & 89 & 11 & 12 & 0 & 47 & 19 & 7 & 0 & 4 & 0 & 8 \\
\hline 4 & 15.26 & 39.26 & 107 & 10 & 3 & 0 & 80 & 14 & 5 & 1 & 4 & 0 & 4 \\
\hline 5 & 18.47 & 69.70 & 55 & 8 & 3 & 1 & 19 & 24 & 12 & 0 & 4 & 2 & 6 \\
\hline 6 & 23.51 & 73.38 & 101 & 4 & 6 & 0 & 60 & 31 & 5 & 3 & 6 & 6 & 11 \\
\hline 7 & 29.74 & 55.88 & 38 & 7 & 5 & 1 & 10 & 15 & 5 & 0 & 3 & 3 & 4 \\
\hline 8 & 30.52 & 53.52 & 31 & 8 & 3 & 0 & 5 & 15 & 5 & 1 & 3 & 2 & 4 \\
\hline 9 & 30.88 & 33.38 & 51 & 2 & 4 & 0 & 31 & 14 & 3 & 0 & 3 & 3 & 5 \\
\hline 10 & 32.20 & 41.89 & 96 & 7 & 6 & 0 & 60 & 23 & 7 & 1 & 5 & 0 & 10 \\
\hline 11 & 38.53 & 42.91 & 109 & 12 & 6 & 1 & 63 & 27 & 11 & 1 & 2 & 1 & 12 \\
\hline 12 & 45.76 & 73.49 & 132 & 12 & 4 & 0 & 77 & 39 & 12 & 1 & 10 & 1 & 15 \\
\hline \multirow[t]{2}{*}{13} & 48.73 & 69.56 & 107 & 20 & 7 & 0 & 58 & 22 & 5 & 0 & 7 & 3 & 7 \\
\hline & & Total & 1123 & 120 & 67 & 3 & 632 & 301 & 101 & 11 & 60 & 23 & 106 \\
\hline
\end{tabular}

Note: $F C=$ proportion of forest cover in the landscape; RER = proportion of the landscape covered by properties declared in the Rural Environmental Registry; Total $=$ number of declared properties inside or intersecting the landscape; No household $=$ number of properties without households; Household outside $=$ number of declared properties whose household is outside the landscape; Two landscapes = number of declared properties that intersect two landscapes; Forest $<1$ ha = number of declared properties encompassing less than 1 ha of forest; Visited = number of visited properties; No resident $=$ number of declared properties without permanent residents; Tenant $=$ number of declared properties whose residents were tenants; Caretaker $=$ number of declared properties whose residents were caretakers (caseiros, in Portuguese); Refuse/inaccessible = number of declared properties whose owners refused to participate in the study or which after three visits were not found; Interview = number of declared properties whose owner (self-declared as the responsible for managing the property) was interviewed. 


\section{Appendix B - Measuring experiences with nature, defining the behavior of interest and measuring the psychological constructs}

Here, we present the questions and/or items and the visual scales used to measure the three variables representing experiences with nature - direct contact with forest, forest use, and losses and damages from forests - and the three psychological variables from the Reasoned Action Approach (RAA) - behavioral beliefs, attitude and intention (Fishbein and Ajzen, 2010). We also explain how we defined the behavior of interest and elicited the beliefs towards this behavior. It is important to highlight, however, that these questions and items were translated from the original sentences in Portuguese, aiming to increase comprehension (for the original sentences, see Appendix C).

\section{Experiences with nature}

- Direct contact with forest:

"In the last month, on how many different days did you go into the forest?"

- Forest use:

"In the last six months, how often did you ?" (1-never / 7-always)

\section{Direct consumptive uses:}

use water coming directly from springs for you or the people living in this house

use water coming directly from springs for your livestock

use water coming directly from springs for irrigating your crops

use forest plants to make medicines

use forest plants to decorate your home and your property

use food that comes from the forest

use forest firewood (including branches)

use forest wood for buildings and fences 


\section{Direct non-consumptive uses:}

consider that you had fun in the forest consider that you enjoyed the forest plants and animals

consider that you felt joy and peaceful by being in the forest or observing the forest

- Losses/damages from forest (or its fauna):

“In the last six months, how often did you ___?? (1-never / 7-always)

\section{$\underline{\text { Related to wildlife: }}$}

have problems with animals that can be dangerous, such as snakes, spiders or wasps

have problems with animals that attack crops, such as wild boars and parrots have problems with animals that attack livestock, such as hawks, lizards, jaguars, foxes, opossums

\section{Others:}

have to buy firewood not to use forest firewood have to buy wood not to use forest wood have less land than you would like to plant, raise animals or construct on this property because of the forest

\section{Behavior of interest}

There are four components to consider when defining the behavior of interest: target, context, time and action, each of which can vary in its levels of generality (Fishbein and Ajzen, 2010). To define these four components, during a pilot study, we informally talked to 30 individuals living in the study region. We first elucidated the target, asking people what they understood when the term "forest" was used, with the objective of selecting the right term designing native forests (i.e., excluding exotic, planted forests, such as eucalyptus forestry, or young native vegetation that still does not have a canopy establishing a proper forest structure). We defined the context of the behavior as limited by the property owned by the participant and the time frame as the period of the next five years. Finally, the action was the most difficult component to define because "to preserve the forest" can imply multiple specific actions, forming 
what in the RAA framework is called a behavioral category (Fishbein and Ajzen, 2010). We asked to pilot participants what they commonly do to "take care" of the forest in their property (i.e., to help maintaining/preserving the integrity of forests), and defined the action component as a group of behaviors: fencing the forest and/or properly maintaining the fence (preventing cattle from entering the forest), guarding and/or putting signs to keep people away from the forest (preventing illegal deforestation, hunting or other types of illegal harvest), removing garbage from the forest, and avoiding (i) the use of fire to clear the land (preventing fires in the forest), (ii) the construction of forest trails or roads, and (iii) clearings and thinning the forest. The description of the actions that constitute the behavior of "taking care of the forest" were included in the protocol as an initial vignette.

\section{Psychological constructs}

- Behavioral beliefs:

During the pilot study, we also elicited the behavioral beliefs, asking participants, in an open-ended question format, all the possible outcomes (i.e., benefits and harms/disadvantages) they think would result from "taking care of the forest in their properties in the next five years". As a result, we obtained 17 benefits and six harms/disadvantages. Benefits were a posteriori classified according to the typology presented in Pascual et al. (2010), into non-use benefits related to altruistic feelings $(n=3)$, direct consumptive uses $(n=8)$, direct non-consumptive uses $(n=3)$ and indirect uses $(n=3)$. We did not classify different types of disadvantages because there is still no consensus in the literature about the best way to do that (e.g., Lyytimäki, 2014; Shackleton et al., 2016; Vaz et al., 2017). Belief strength and evaluation was assessed using the following questions. 


\section{Benefits/advantages:}

\section{Strength}

"If you take care of the forest in this property for the next five years, will this make you ?" (noway-1/ surely-7)

$\underline{\text { Use }}$

$\underline{\text { Direct }}$

\section{Consumptive}

more assured of having water from springs for you and the people living in this house

more assured of having water from springs for your livestock

more assured of having water from springs for irrigating your crops

have more plants to make medicines

have more plants to decorate your home and your property

have more food that comes from nature

have more firewood

have more wood for constructions and fences

\section{$\underline{\text { Non-consumptive }}$}

have more fun in nature

appreciate more the plants and animals

feel more joy and peaceful by being in nature or observing nature

\section{$\underline{\text { Indirect }}$}

breathe cleaner air

have a cooler and more pleasant climate

have cleaner water

\section{Non-use}

pleased to know that plants and animals can continue to exist pleased to know that other people besides you can continue to enjoy nature pleased to know that your children and grandchildren will enjoy nature 


\section{Evaluation}

"How essential is that you ?" (nothing essential-1 / very essential-7)

$\underline{\text { Use }}$

Direct

\section{Consumptive}

have water from springs for you and the people living in this house have water from springs for your livestock have water from springs to irrigate your crops have plants to make medicines have plants to decorate your home and your property have food that comes from nature have firewood have wood for constructions and fences

\section{Non-consumptive}

have fun in nature

appreciate the plants and animals

feel joy and peaceful by being in nature or observing nature

\section{Indirect}

breathe cleaner air

have a cooler and more pleasant climate

have cleaner water

\section{$\underline{\text { Non-use }}$}

know that plants and animals can continue to exist know that other people can continue to enjoy nature know that your children and grandchildren will enjoy nature 


\section{Harms/disadvantages:}

\section{$\underline{\text { Strength }}$}

"If you take care of the forest in this property for the next five years, this will make you ?" (noway-1/ surely-7)

$\underline{\text { Related to wildlife: }}$

more likely to have problems with animals that can be dangerous, such as snakes, spiders or wasps

more likely to have problems with animals that attack crops, such as wild boars and parrots

more likely to have problems with animals that attack livestock, such as hawks, lizards, jaguars, foxes, opossums

\section{Others:}

spend more money buying firewood

spend more money buying wood for constructions and fences

have less land than you would like to plant, raise animals or construct

\section{Evaluation}

"How severe is that you ?" (nothing bad-1 / very bad-7)

Related to wildlife:

have problems with animals that can be dangerous, such as snakes, spiders or wasps

have problems with animals that attack crops, such as wild boars and parrots have problems with animals that attack livestock, such as hawks, lizards, jaguars, foxes, opossums

\section{Others:}

spend more money buying firewood spend more money buying wood for constructions and fences have less land than you would like to plant, raise animals or construct 
- Attitude:

"What do you think about taking care of the forest in this property for the next five years? Please, show me in this scale how or this would be" $(-3$ to +3$)$ Instrumental aspect:

useless / useful

harmful / beneficial

$\mathrm{bad} / \operatorname{good}$

\section{Experiential aspect:}

unpleasant / pleasant

boring / interesting

tiring / encouraging

\section{- Intention:}

"Considering what you intend to do in the forest of this property for the next five years, how much do you agree with the following sentences: you take care of the forest in this property." (not even a little-1 / a lot-7)

\section{Positive sentences:}

want to

are making plans to

will make an effort to

are motivated to

\section{Negative sentences:}

are discouraged to

are lazy to

have little disposition to

have little interest to

\section{Visual scales}

We used two types of visual scales (Figure B1) to help participants respond to the items in the indices of forest use, losses and damages from forest and of behavioral beliefs, and in the scales of attitude and intention. Although in the visual scales the numbers in the circles are from 0 to 6 , we coded them as 1 to 7 and -3 to +3 for the 
unipolar and bipolar scales, respectively. This was done for two reasons. First, as the numbers served just to facilitate the participants pointing their choices (i.e., the circle position), we intended to make clear the value of the lower categories (e.g., never, no way) in responses related to frequencies or level of agreement (i.e., unipolar scales). Second, to avoid an undesirable response bias, with participant choosing only the +3 option in the bipolar scale. The bipolar scale was used with a color gradation between blue (response category - 0) to orange (response category -7 ).

\section{Unipolar}
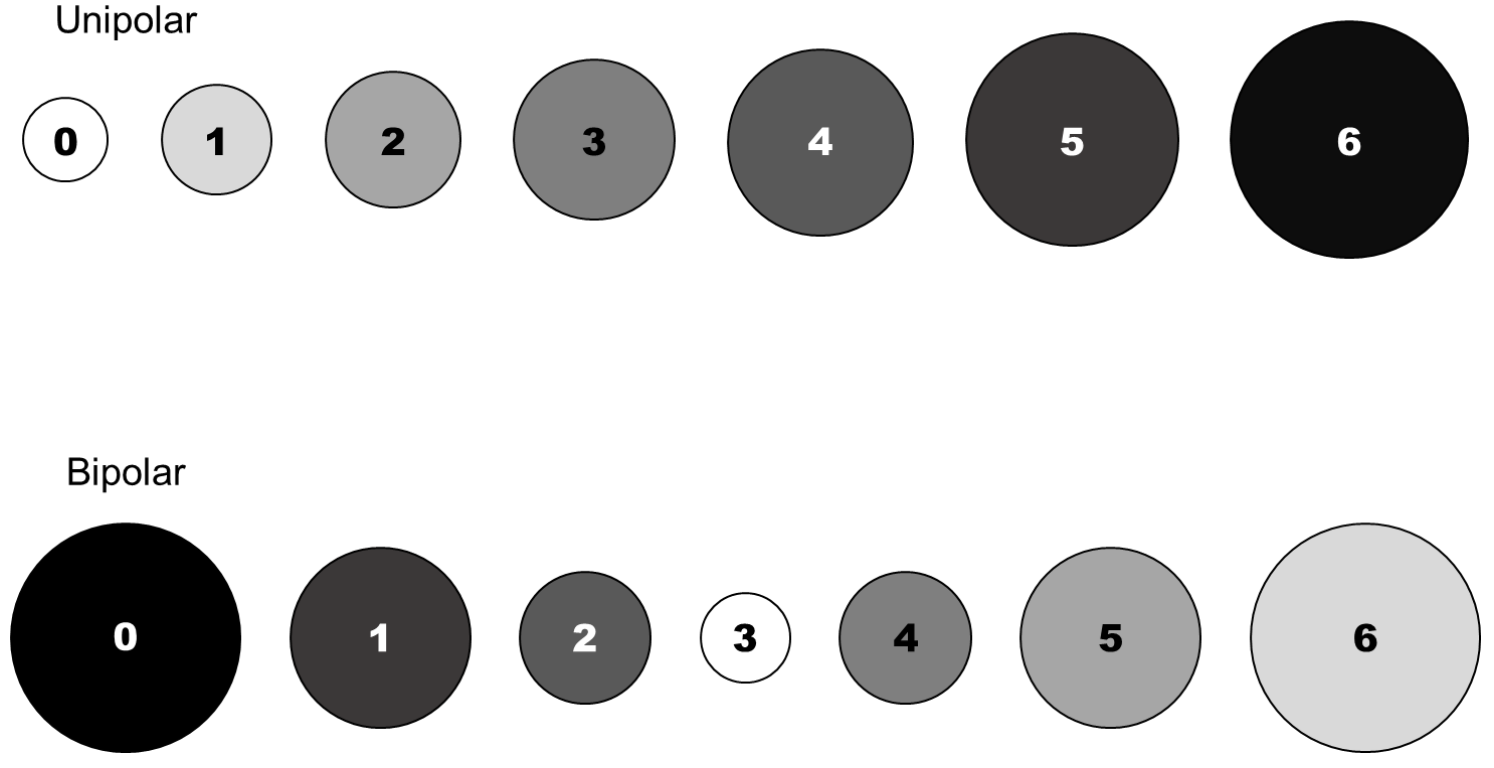

Figure B1: Visual response scales used during the interview. Unipolar - used to measure the indices of forest uses, losses/damages from forest and beliefs and to measure the scale of intention. Bipolar - used to measure the attitude scale, originally it was presented in colors from blue to orange.

\section{References}

Fishbein, M., Ajzen, I., 2010. Predicting and changing behavior: the reasoned action approach. Psychology Press, New York. 
Lyytimäki, J., 2014. Bad nature: Newspaper representations of ecosystem disservices. Urban Forestry \& Urban Greening 13, 418-424. https://doi.org/10.1016/j.ufug.2014.04.005

Pascual, U., Muradian, R., Brander, L., Gómez-Baggethun, E., Martín-López, B., Verma, M., Armsworth, P., Christie, M., Cornelissen, H., Eppink, F., Farley, J., Loomis, J., Pearson, L., Perrings, C., Polasky, S., 2010. The economics of valuing ecosystem services and biodiversity, in: The Economics of Ecosystems and Biodiversity (TEEB): The Ecological and Economic Foundations. Earthscan, London and Washington.

Shackleton, C.M., Ruwanza, S., Sanni, G.K.S., Bennett, S., Lacy, P.D., Modipa, R., Mtati, N., Sachikonye, M., Thondhlana, G., 2016. Unpacking Pandora's Box: Understanding and Categorising Ecosystem Disservices for Environmental Management and Human Wellbeing. Ecosystems 19, 587-600. https://doi.org/10.1007/s10021-015-9952-z

Vaz, A.S., Kueffer, C., Kull, C.A., Richardson, D.M., Vicente, J.R., Kühn, I., Schröter, M., Hauck, J., Bonn, A., Honrado, J.P., 2017. Integrating ecosystem services and disservices: insights from plant invasions. Ecosystem Services 23, 94-107. https://doi.org/10.1016/j.ecoser.2016.11.017 


\section{Appendix C - Protocol applied by face-to-face interviews}

Below, we present the whole, original protocol in Portuguese used in face-to-face interviews with participants. The protocol contains not only the questions to assess the variables used in this paper, but also extra questions regarding a larger research project aiming at understanding how ecological context influences the relation between humans and nature. For the translated questions and items associated with the variables used in this paper, see Appendix B. 


\section{UNIVERSIDADE DE SÃO PAULO Instituto de Biociências}

Projeto: Como varia a intenção de preservar a floresta em populações que habitam paisagens com diferentes porcentagens de cobertura florestal remanescente?
Data de entrevista:

$/ 2017$

Entrevista por:

Registro da Propriedade (ponto no GPS):

\section{Georreferência:}

Latitude (S):

Longitude (W):

\begin{tabular}{|c|c|c|c|c|}
\hline Etapa & $\begin{array}{c}\text { Nome do } \\
\text { responsável }\end{array}$ & Data & $\begin{array}{c}\text { Situação dos dados (OK } \\
\text { ou dados faltantes-DF) }\end{array}$ & $\begin{array}{c}\text { Dados faltantes (indicar as } \\
\text { seções e questões com DF) }\end{array}$ \\
\hline Revisão & & & & \\
\hline Planilha & & $/ 2017$ & & \\
\hline
\end{tabular}

\section{Identificação da propriedade}

\begin{tabular}{|l|l|l}
\hline Paisagem:____ Código da propriedade: & Propriedade:__ & Con _
\end{tabular}

Entrevistado(a): Qual o nome completo do(a) senhor(a)?

Nota: Os trechos em itálico são instruções ao entrevistador e não devem ser lidas à pessoa entrevistada.

Nota: Ler ao(à) potencial entrevistado(a) antes de começar as perguntas:

1. Bom dia/Boa tarde, nós somos estudantes de São Paulo e estamos fazendo uma pesquisa para entender melhor qual é a opinião dos moradores da zona rural aqui da região sobre a natureza e as matas, quais coisas que os moradores costumam fazer quando vão na mata e como é a mata nas propriedades deles.

Nota: Perguntar para TODOS:

2. O(A) senhor(a) mora aqui nesta propriedade? E essa propriedade é do(a) senhor(a)?

Nota: Se NÃO para alguma das duas perguntas do item 2:

3. E o(a) senhor(a) saberia de algum proprietário que mora aqui, que tenha uma mata de pelo menos 1 ha com quem poderíamos conversar? Agradecer e encerrar a conversa.

Nota: Se SIM para ambas as perguntas do item 2:

4. É o(a) senhor(a) quem mais toma conta da propriedade? Se NÃO, com quem poderíamos conversar?

Nota: Se NÃO para a pergunta do item 4, falar com a pessoa encarregada da propriedade.

Nota: Perguntar para MORADORES(AS) E PROPRIETÁRIOS(AS) ENCARREGADOS(AS) DE CUIDAR DA PROPRIEDADE:

5. O(A) senhor(a) teria um tempinho para nos ajudar? Nossa conversa deve demorar cerca de uma hora e meia, mas se estiver muito ocupado(a) agora, não tem problema, podemos combinar de voltar quando for melhor para o(a) senhor(a).

Gostaríamos desde já de agradecer a participação do(a) senhor(a) neste estudo. Pedimos licença para anotar as respostas porque é muita coisa para lembrarmos de cabeça e para não nos confundirmos depois. Por favor, se ao longo da entrevista o(a) senhor(a) tiver alguma dúvida, não deixe de perguntar. 


\section{I - DADOS SOCIODEMOGRÁFICOS E CARACTERÍSTICAS DA PROPRIEDADE - PARTE I}

Nota: Ler ao(à) entrevistado(a) antes de começar as perguntas:

Vou fazer primeiro algumas perguntas mais gerais sobre o(a) senhor(a) e sobre esta propriedade.

1.1. Sexo: Feminino I__ Masculino I__

1.2.1. Tempo na propriedade: Há quanto tempo o(a) senhor(a) mora nesta propriedade?

I__ l anos I__ I meses

I__ I desde que nasceu - Se desde que nasceu, perguntar: $\mathrm{E}$ isso faz cerca de quantos anos?

1.2.2. Local de nascimento: Em qual cidade, estado e país o(a) senhor(a) nasceu?

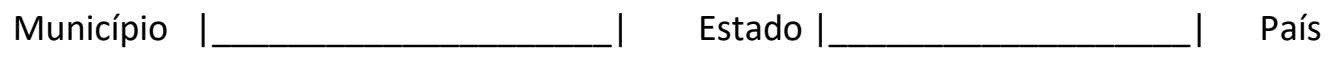

1.2.3. Contexto antecedente: Até os seus 10 anos de idade, o(a) senhor(a) e sua família passaram quantos anos morando na cidade e na zona rural? (anotar número de anos) Cidade | | Zona rural|

1.3. Tamanho da propriedade: Qual é o tamanho desta propriedade? (marcar a unidade abaixo) Alqueires I__ Hectares I__ I Metros quadrados I__ Outra Não sabe

1.4. Presença e quantidade de mata: $\mathrm{O}(\mathrm{A})$ senhor(a) disse que tem uma área de mata nesta propriedade. Qual é o tamanho dessa área de mata? (marcar a unidade abaixo)

Alqueires I__ Hectares I__ Metros quadrados I__ O Outra Não sabe

1.5.1. Reserva legal e APP: $O(A)$ senhor(a) tem ideia se o tamanho da área de mata desta propriedade é menor, igual ou maior do que a lei pede?

Menor I__ Igual I__ I Maior I__ Não sei I__ I

Nota: Se IGUAL, MAIOR ou NÃO SEI, ir para a pergunta 1.6.1.

1.5.2. Reserva legal e APP: $O(A)$ senhor(a) faz ideia de quanto de mata o(a) senhor(a) precisaria ter para atingir a área de mata que a lei pede?
Sim, sei I
|Quanto?
Nada I
Não, não sei l__l

1.6.1. $O(A)$ senhor(a) conhece algum projeto ou iniciativa que ajuda os moradores aqui da região a cuidarem das suas matas?

$\operatorname{Sim}$ I__ Quais?

Não|___ Nota: Se NÃO, pular a próxima questão

1.6.2. Projetos: E o(a) senhor(a) participa de algum desses projetos?

Sim I__ l Quais?

Não | 


\section{II - CONTATO COM A FLORESTA}

Nota: Ler ao(à) entrevistado(a) antes de começar as perguntas:

Nesta parte da entrevista, gostaria de saber se o(a) senhor(a) costumava ir na mata quando o(a) senhor(a) era pequeno(a), o que costuma fazer quando ia na mata na infância e também sobre as vezes que o(a) senhor(a) costuma ir na mata atualmente.

2.1 Proximidade da mata na infância: Pensando no tempo que o(a) senhor(a) era pequeno, até os seus 10 anos, gostaria de saber quão longe era a mata mais próxima da sua casa. $O(A)$ senhor(a) poderia me dizer se dava menos de 10 minutos andando a pé, entre 10 e 30 minutos ou mais de 30 minutos? Se o(a) senhor(a) morou em vários lugares quando era pequeno(a), considere o lugar em que passou a maior parte da infância.

Menos de 10 minutos $\mid \ldots$ entre 10 e 30 minutos $\mid$ mais de 30 minutos |

Não sei |

2.2 Visitas na infância: $O(A)$ senhor(a) costumava ir na mata quando era pequeno(a), até cerca dos seus 10 anos? Sim I__ N Nãol__ _ Não sei I__ N Nota: Se NÃO ou NÃO SEI, ir para a pergunta 2.4.

2.3 Motivo das visitas na infância: Gostaria de saber o que o(a) senhor(a) costumava fazer na mata quando era pequeno(a), até os seus 10 anos. Vou falar várias coisas que as crianças costumam fazer na mata e gostaria que o(a) senhor(a) apontasse nesta folha (mostrar a folha com a escala) com que frequência ia na mata fazer cada uma dessas coisas quando era pequeno(a). A bola menor é se o(a) senhor(a) nunca fazia essas coisas (apontar a bola menor) e a bola maior que é se o(a) senhor(a) fazia sempre (apontar a bola maior). Quanto maior a bola, mais o(a) senhor(a) fazia essas coisas (correr o dedo da bola menor para a maior).

\begin{tabular}{|c|c|c|c|c|c|c|c|}
\hline Atividade & $\mathrm{Nu}$ & & & & & & npre \\
\hline 2.3.1 Passear ou brincar & 1 & 2 & 3 & 4 & 5 & 6 & 7 \\
\hline 2.3.2 Nadar & 1 & 2 & 3 & 4 & 5 & 6 & 7 \\
\hline 2.3.3 Apreciar as plantas e os animais & 1 & 2 & 3 & 4 & 5 & 6 & 7 \\
\hline 2.3.4 Se locomover entre casas, bairros ou diferentes locais & 1 & 2 & 3 & 4 & 5 & 6 & 7 \\
\hline 2.3.5 Buscar coisas para ajudar no sustento da família & 1 & 2 & 3 & 4 & 5 & 6 & 7 \\
\hline 2.3.6 Buscar animais de criação que escapavam & 1 & 2 & 3 & 4 & 5 & 6 & 7 \\
\hline Alguma outra coisa? O quê? Com qual frequência? & & & & & & & \\
\hline 2.3.7 & 1 & 2 & 3 & 4 & 5 & 6 & 7 \\
\hline
\end{tabular}

\subsection{Visitas na mata:}

2.4.1 E pensando no tempo de agora, já adulto(a), o(a) senhor(a) foi na mata, mesmo que rapidamente, nesse último mês, ou seja, do dia de (preencher com o dia e mês de um mês atrás) deste ano até hoje? Sim I Não|

Nota: Se NÃO, perguntar só para os três meses. Se SIM, perguntar até a 4.3. para um mês e depois voltar perguntar para os três meses.

2.4.2 E pensando num tempo maior, nos últimos três meses, desde o dia de (preencher com o dia e mês de três meses atrás) deste ano, o(a) senhor(a) foi na mata/alguma outra vez na mata além dessa(s) vez(es) que o(a) senhor já nos contou (dependendo do que a pessoa respondeu antes), mesmo que rapidamente? Sim I Não| Nota: Se NÃO, ir para a SEÇÃO III. 


\subsection{Frequência de visitas:}

2.5.1 Em quantos dias diferentes o(a) senhor(a) foi na mata nesse último mês, do dia de (preencher com o dia e mês de um mês atrás) deste ano até hoje? Por favor, considere mesmo as vezes que foram rápidas (menos de meia hora)

2.5.2 Ler para quem foi no último mês: Além daqueles dias que o(a) senhor(a) já falou (preencher com o número de dias da pergunta 2.5.1)

Ler para todos: Em quantos dias diferentes o(a) senhor(a) foi na mata desde o dia de (preencher com o dia e mês de um mês atrás) deste ano, mesmo que rapidamente?

\subsection{Duração das visitas:}

2.6.1 Desses dias (preencher com o número de dias da pergunta 2.5.1) em que o(a) senhor(a) foi na mata, o(a) senhor(a) poderia me dizer em quantos deles o(a) senhor(a) ficou (ler cada alternativa):

Menos de 1 hora? de $1 \mathrm{~h}$ a 4 horas? I mais de 4 horas?

2.6.2 E desses outros dias (preencher com o número de dias da pergunta 2.5.2) em que o(a) senhor(a) foi na mata, em quantos deles o(a) senhor(a) ficou (ler cada alternativa):

Menos de 1 hora? de $1 \mathrm{~h}$ a 4 horas? mais de 4 horas?

\subsection{Motivo das visitas:}

2.3.1 Gostaria de saber agora por que o(a) senhor(a) foi na mata nesses dias. $\mathrm{O}(\mathrm{A})$ senhor(a) poderia, por gentileza, me dizer o que o(a) senhor(a) foi fazer na mata? (deixar a resposta livre, anotar na categoria mais adequada ou em outros e depois só confirmar os itens em branco).

Nota: Para os itens em BRANCO: Algum dia, o(a) senhor(a) foi na mata:

2.3.2 E nesses outros dias que o(a) senhor(a) foi na mata, o(a) senhor(a) foi fazer o que? (deixar a resposta livre $e$ depois só confirmar os itens em branco).

\begin{tabular}{|l|l|l|}
\hline Motivo & \multicolumn{2}{c|}{ Quantos dias? } \\
\cline { 2 - 3 } & $\mathbf{1 ~ m e ̂ s}$ & $\mathbf{3}$ meses \\
\hline $\mathbf{1} \square$ Para buscar algum animal de criação que escapou & & \\
\hline $\mathbf{2} \square$ Para se locomover entre casas, bairros ou locais diferentes & & \\
\hline $\mathbf{3} \square$ Para cuidar da mina d'água & & \\
\hline $\mathbf{4} \square$ Para cuidar da cerca & & \\
\hline $\mathbf{5} \square$ Para buscar alguma planta para fazer remédios & & \\
\hline $\mathbf{6} \square$ Para buscar alguma planta para enfeitar a sua casa ou sua propriedade & & \\
\hline $\mathbf{7} \square$ Para buscar algum tipo de comida & & \\
\hline $\mathbf{8} \square$ Para buscar lenha (explicar que podem ser galhos) & & \\
\hline $\mathbf{9} \square$ Para buscar madeira para construções e cercas & & \\
\hline $\mathbf{1 0} \square$ Só para se divertir & & \\
\hline $\mathbf{1 1} \square$ Só para apreciar as plantas e os animais & & \\
\hline $\mathbf{1 2} \square$ Só para ter uma sensação de alegria, paz ou tranquilidade & & \\
\hline Outras coisas: & & \\
\hline $\mathbf{1 3} \square$ & & \\
\hline Total: (anotar o total e se der menos do que da pergunta 2.5. verificar) & & \\
\hline
\end{tabular}




\section{III - ESCALA LIKERT DAS CRENÇAS}

Nota: Ler ao(à) entrevistado(a) antes de começar as perguntas:

Agora, vou falar várias frases e gostaria que o(a) senhor(a), da mesma forma como fez antes, mostrasse aqui (apontar a escala) o quanto o(a) senhor(a) concorda com elas. Pode ser que alguma das frases que eu falar pareça estranha ou errada para o(a) senhor(a), nesses casos não tem problema se o(a) senhor(a) não concordar nem um pouco com a frase. A bola menor é se o(a) senhor(a) não concorda nem um pouco com a frase e quanto maior a bola mais o(a) senhor(a) concorda com a frase. A bola maior é se o(a) senhor(a) concordar muito com a frase. Não existe uma resposta certa ou errada, o que vale é a opinião do(a) senhor(a).

\begin{tabular}{|c|c|c|c|c|c|c|c|}
\hline $\begin{array}{l}\text { 3. Por favor, mostre na escala o quanto o(a) senhor(a) concorda com cada uma das frases } \\
\text { que eu vou falar. }\end{array}$ & & & & & & Mu & \\
\hline 3.1. Seria bom poder usar a área da mata para outra coisa mais proveitosa. & 7 & 6 & 5 & 4 & 3 & 2 & 1 \\
\hline 3.2. A morte das plantas e dos animais da mata entristece. & 1 & 2 & 3 & 4 & 5 & 6 & 7 \\
\hline 3.3. Manter tudo aquilo que existe dentro das matas traz alegria. & 1 & 2 & 3 & 4 & 5 & 6 & 7 \\
\hline $\begin{array}{l}\text { 3.4. Ter mata é pouco importante porque os produtos que vêm da mata são } \\
\text { desnecessários. }\end{array}$ & 7 & 6 & 5 & 4 & 3 & 2 & 1 \\
\hline 3.5. Tudo que se pode pegar da mata é bom para as pessoas. & 1 & 2 & 3 & 4 & 5 & 6 & 7 \\
\hline 3.6. A mata é boa porque dá muita água. & 1 & 2 & 3 & 4 & 5 & 6 & 7 \\
\hline 3.7. Os produtos que vêm da mata são inúteis. & 7 & 6 & 5 & 4 & 3 & 2 & 1 \\
\hline 3.8. Saber que as plantas e animais da mata continuam vivendo traz felicidade. & 1 & 2 & 3 & 4 & 5 & 6 & 7 \\
\hline 3.9. Não importa se a mata desaparecer. & 7 & 6 & 5 & 4 & 3 & 2 & 1 \\
\hline 3.10. Saber que as matas existem traz desânimo. & 7 & 6 & 5 & 4 & 3 & 2 & 1 \\
\hline 3.11. As matas são importantes porque fornecem comida para as pessoas. & 1 & 2 & 3 & 4 & 5 & 6 & 7 \\
\hline 3.12. O desaparecimento das plantas e animais da mata é um problema pe & 7 & 6 & 5 & 4 & 3 & 2 & 1 \\
\hline
\end{tabular}

\section{IV - INTENÇÃO DE PRESERVAR A FLORESTA}

Nota: Ler ao(à) entrevistado(a) antes de começar as perguntas:

Nesta parte da entrevista, vamos falar sobre o cuidar da mata. Uma pessoa pode cuidar da mata de muitas formas, como por exemplo:

- cercando a mata e dando manutenção na cerca, de maneira a evitar que o gado ou as pessoas fiquem entrando e andando na mata

- vigiando ou colocando placas e sinais para não deixar pessoas desconhecidas entrarem e pegarem plantas ou animais da mata,

- retirando o lixo encontrado na mata

- evitando fazer picadas e trilhas na mata, por onde poderiam passar muitas pessoas

- evitando o uso do fogo para limpar o terreno, que poderia incendiar a mata

- ou apenas deixando a mata lá, evitando cortar árvores, abrir clareiras ou pequenas estradas

Apesar de existirem outras formas de uma pessoa cuidar da mata, nessa nossa conversa vamos considerar só essas formas de cuidar da mata (cercar e dar manutenção na cerca, vigiar, retirar o lixo, evitar fazer picadas e trilhas, evitar o uso de fogo, e evitar cortar árvores, abrir clareiras ou estradas). 
Vou falar várias frases e gostaria primeiro que o(a) senhor(a) me indicasse o quanto acha que certas coisas vão de fato acontecer se o(a) senhor(a) cuidar da sua mata que está nesta propriedade. Para cada frase, por gentileza, mostre sua resposta nas bolas dessa folha. A bola menor é para coisas que o(a) senhor(a) acha que não acontecerão de maneira nenhuma. Quanto maior o tamanho da bola, quer dizer que tem mais chance de acontecer. A bola maior é para coisas que o(a) senhor(a) acha que acontecerão com toda a certeza.

Depois, gostaria que o(a) senhor(a) me dissesse o quanto cada uma dessas coisas são essenciais para a sua vida e para as decisões que o(a) senhor(a) toma, desde nada essencial, ou seja, o(a) senhor(a) pode viver bem sem isso porque não faz muita falta para o(a) senhor(a) (apontar a bola menor), até muito essencial (apontar a bola maior), ou seja, algo que o(a) senhor(a) precisa muito e faz muita falta se o(a) senhor(a) não tiver. Para cada frase, mostre, por favor, sua resposta, na escala.

4.1. Força das crenças de uso e dos prejuízos: Se o(a) senhor(a) cuidar da mata desta propriedade pelos próximos cinco anos, isso vai fazer com que o(a) senhor(a)

Maneira nenhuma
Toda certeza
4.2. Avaliação das crenças de uso: Para o(a) senhor(a) viver bem, quão essencial para o(a) senhor(a) é
Nada essencial
Muito essencial

\section{Benefício de uso direto consumível}

4.1.1. Tenha mais garantia de ter água das minas de nascentes para o(a) senhor(a) e as pessoas que moram nessa casa

4.1.2. Tenha mais garantia de ter água das minas de nascentes para seus animais de criação

4.1.3. Tenha mais garantia de ter água das minas de nascentes para irrigar suas plantações

4.1.4. Tenha mais plantas para fazer remédios

4.1.5. Tenha mais plantas para enfeitar a sua casa e sua propriedade

4.1.6. Tenha mais comida que vem da natureza

4.1.7. Tenha mais lenha

4.1.8. Tenha mais madeira para construções e cercas

(a)

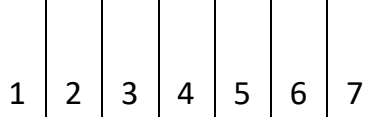 \begin{tabular}{|lll|l|l|l|l|l}
1 & 2 & 3 & 4 & 5 & 6 & 7 \\
\hline
\end{tabular}}

\begin{tabular}{ll|l|l|l|l|l|l|} 
& & & & & casa \\
\hline
\end{tabular}

4.2.1. Ter água das minas de nascentes para o(a) senhor(a) e as pessoas que moram nessa casa

4.2.2. Ter água das minas de

\begin{tabular}{|l|l|l|l|l|l|l|l} 
nascentes para seus animais de & 1 & 2 & 3 & 4 & 5 & 6 & 7
\end{tabular} criação

4.2.3. Ter água das minas de \begin{tabular}{ll|l|l|l|l|l|l|l|} 
nascentes para irrigar suas & 1 & 2 & 3 & 4 & 5 & 6 & 7
\end{tabular} plantações

4.2.4. Ter plantas para fazer remédios $\begin{array}{lllllllll}1 & 2 & 3 & 4 & 5 & 6 & 7\end{array}$ $\begin{array}{lllllllll}1 & 2 & 3 & 4 & 5 & 6 & 7\end{array}$ 4.2.5. Ter plantas para enfeitar a sua casa ou sua propriedade

4.2.6. Ter comida que vem da natureza

\begin{tabular}{l|l|l|l|l|l|l}
1 & 2 & 3 & 4 & 5 & 6 & 7 \\
\hline
\end{tabular}

4.2.7. Ter lenha

4.2.8. Ter madeira construções e cercas

\section{Benefício de uso direto não consumível}

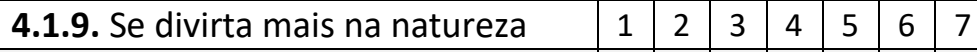
4.1.10. Aprecie mais as plantas e animais

4.1.11. Sinta uma maior sensação de alegria, paz e tranquilidade por estar na natureza ou observar a natureza
4.2.9. Se divertir na natureza 4.2.10. Apreciar as plantas e animais

4.2.11. Ter a sensação de alegria, paz e tranquilidade por estar na natureza ou observar a natureza

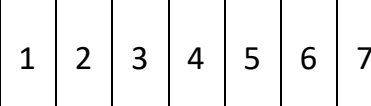
\begin{tabular}{l|l|l|l|l|l|l}
1 & 2 & 3 & 4 & 5 & 6 & 7
\end{tabular} \begin{tabular}{l|l|l|l|l|l|l}
1 & 2 & 3 & 4 & 5 & 6 & 7
\end{tabular} \begin{tabular}{l|l|l|l|l|l|l}
1 & 2 & 3 & 4 & 5 & 6 & 7
\end{tabular}

\begin{tabular}{|l|l|l|l|l|l|l|l|} 
& 1 & 2 & 3 & 4 & 5 & 6 & 7 \\
\hline & 1 & 2 & 3 & 4 & 5 & 6 & 7
\end{tabular}

1

\begin{tabular}{|l|l|l|l|l|l|l|l|}
\hline & 1 & 2 & 3 & 4 & 5 & 6 & 7 \\
\hline & 1 & 2 & 3 & 4 & 5 & 6 & 7 \\
\hline$r$ & 1 & 2 & 3 & 4 & 5 & 6 & 7 \\
\hline
\end{tabular}


Benefício de uso indireto

\begin{tabular}{|c|c|c|c|c|c|c|c|c|c|c|c|c|c|c|c|}
\hline 4.1.12. Respire um ar mais puro & 1 & 2 & 3 & 4 & 5 & 6 & 7 & $\begin{array}{l}\text { 4.2.12. Respirar um ar mais } \\
\text { puro }\end{array}$ & 1 & 2 & 3 & 4 & 5 & 6 & 7 \\
\hline $\begin{array}{l}\text { 4.1.13. Tenha um clima mais fresco e } \\
\text { agradável }\end{array}$ & 1 & 2 & 3 & 4 & 5 & 6 & 7 & $\begin{array}{l}\text { 4.2.13. Ter um clima mais } \\
\text { fresco e agradável }\end{array}$ & 1 & 2 & 3 & 4 & 5 & 6 & 7 \\
\hline 4.1.14. Tenha água mais pura & 1 & 2 & 3 & 4 & 5 & 6 & 7 & 4.2.14. Ter água mais pura & 1 & 2 & 3 & 4 & 5 & 6 & 7 \\
\hline
\end{tabular}

4.1.15. Fique muito satisfeito(a) por \begin{tabular}{l|l|l|l|l|l|l|l} 
saber que plantas e animais podem & 1 & 2 & 3 & 4 & 5 & 6 & 7
\end{tabular} continuar a existir

4.1.16. Fique muito satisfeito(a) por saber que outras pessoas, além do(a) senhor(a), podem continuar aproveitando a natureza

4.1.17. Fique muito satisfeito(a) por saber que seus filhos e netos vão poder aproveitar a natureza

Prejuízos: Se o(a) senhor(a) cuidar da mata desta propriedade
pelos próximos cinco anos, isso vai fazer com que o(a)
senhor(a)

4.2.15. Saber que plantas e

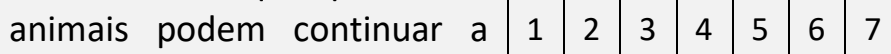
existir

\begin{tabular}{|l|l|l|l|l|l|l|l|}
\hline $\begin{array}{l}\text { 4.1.18. Tenha mais chance de ter } \\
\text { problemas com animais que podem } \\
\text { ser perigosos, como cobras, aranhas }\end{array}$ & 7 & 6 & 5 & 4 & 3 & 2 & 1
\end{tabular} ou vespas

4.1.19. Tenha mais chance de ter problemas com animais que atacam as plantações, como javalis e maritacas

4.1.20. Tenha mais chance de ter problemas com animais que atacam criações, como gavião, lagarto, onça, cachorro-do-mato, gambá

4.1.21. Tenha que gastar mais dinheiro comprando lenha

4.1.22. Tenha que gastar mais

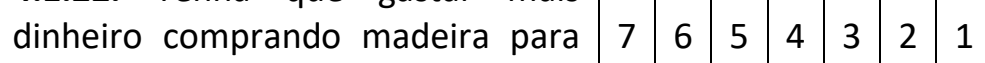
construções e cercas

4.1.23. Tenha menos espaço do que gostaria para plantar, criar animais ou construir

\begin{tabular}{|l|l|l|l|l|l|l|l}
7 & 6 & 5 & 4 & 3 & 2 & 1
\end{tabular}

4.2.16. Saber que outras

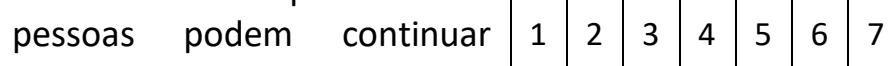
aproveitando a natureza

4.2.17. Saber que seus filhos e

\begin{tabular}{l|l|l|l|l|l|l|l} 
netos vão poder aproveitar a & 1 & 2 & 3 & 4 & 5 & 6 & 7
\end{tabular} natureza

Avaliação das crenças dos prejuízos: (mudar a escala) Agora pensando em uma escala de uma coisa que pode ser nada ruim (apontar a bola menor) até muito ruim (apontar a bola maior), o quanto o(a) senhor(a) acha ruim

\section{Nada ruim Muito ruim}

4.2.18. Ter problemas com animais que podem ser

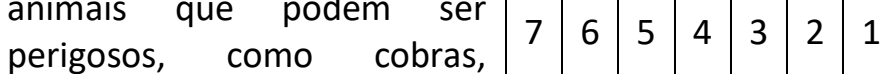
aranhas ou vespas

4.2.19. Ter problemas com animais que atacam

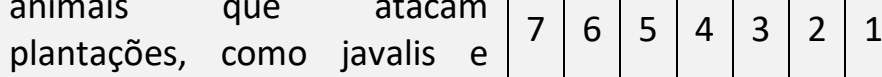
maritacas

4.2.20. Ter problemas com animais que atacam criações, como gavião, lagarto, onça, cachorro-do-mato, gambá

\begin{tabular}{|l|l|l|l|l|l|l}
7 & 6 & 5 & 4 & 3 & 2 & 1 \\
\hline
\end{tabular}

4.2.21. Gastar comprando lenha

4.2.22. Gastar dinheiro

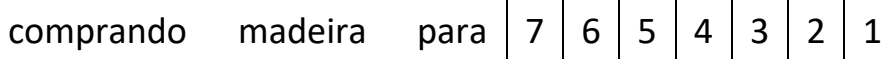
construções e cercas

4.2.23. Ter menos espaço do que gostaria para plantar, criar animais ou construir $\begin{array}{lllllllll}7 & 6 & 5 & 4 & 3 & 2 & 1\end{array}$ $\begin{array}{lllllll}7 & 6 & 5 & 4 & 3 & 2 & 1\end{array}$ \begin{tabular}{l|l|l|l|l|l|l|l} 
dinheiro & 7 & 6 & 5 & 4 & 3 & 2 & 1
\end{tabular} $\begin{array}{lllllllll}7 & 6 & 5 & 4 & 3 & 2 & 1\end{array}$ 
Nota: Ler ao(à) entrevistado(a) antes de começar as perguntas:

Para as frases que vou falar a seguir gostaria que o(a) senhor(a) novamente me indicasse o quanto concorda com cada uma delas, sendo a bola menor para uma frase que o(a) senhor(a) não concorda nem um pouco e a bola maior para uma frase que o(a) senhor(a) concorda muito. Não existe uma resposta certa ou errada, o que vale é a opinião do(a) senhor(a). Lembrando que estamos considerando "cuidar da mata" como:

- cercar a mata e dar manutenção na cerca, de maneira a evitar que o gado ou pessoas fiquem entrando e andando na mata

- vigiar ou colocar placas e sinais para não deixar pessoas desconhecidas entrarem e pegarem plantas ou animais da mata,

- retirar o lixo encontrado na mata

- evitar fazer picadas e trilhas na mata, por onde poderiam passar muitas pessoas

- evitar o uso do fogo para limpar o terreno, que poderia incendiar a mata

- ou apenas deixar a mata lá, evitando cortar árvores, abrir clareiras ou pequenas estradas

Primeiro gostaria de saber o que o(a) senhor(a) acha que as outras pessoas pensam sobre o(a) senhor(a) cuidar da mata e depois se o(a) senhor(a) acha que elas vão cuidar da mata.

\subsection{Norma Percebida:}

Nem um pouco

4.3.1. Injuntiva: $\mathrm{O}(\mathrm{A})$ senhor(a) acha que as pessoas que eu vou falar a seguir pensam que o(a) senhor(a) deveria cuidar da mata desta propriedade pelos próximos cinco anos? Por favor, mostre na escala o quanto o(a) senhor(a) concorda que

4.3.1.1. A maioria das pessoas que o(a) senhor(a) conhece acha que o(a) senhor(a) deveria cuidar da mata desta propriedade.

4.3.1.2. A maioria das pessoas que são importantes para o(a) senhor(a), como sua família e amigos, acha que o(a) senhor(a) deveria cuidar da mata desta propriedade.

4.3.1.3. A maioria dos líderes religiosos que são importantes para o(a) senhor(a), como padres ou pastores, ou líderes de outras religiões, acha que o(a) senhor(a) deveria cuidar da mata desta propriedade.

4.3.1.4. A maioria das pessoas que moram perto do(a) senhor(a), como seus vizinhos e pessoas da comunidade ou região, acha que o(a) senhor(a) deveria cuidar da mata desta propriedade.

4.3.2. Descritiva: Perguntei sobre o que o(a) senhor(a) acha que outras pessoas pensam do(a) senhor(a) cuidar da mata desta propriedade. Agora gostaria de saber se o(a) senhor(a) acha que as pessoas que vou falar a seguir vão cuidar das matas das propriedades delas pelos próximos cinco anos. Por favor, mostre na escala o quanto o(a) senhor(a) concorda que

4.3.2.1. A maioria das pessoas que o(a) senhor(a) conhece vai cuidar da mata das propriedades delas.

4.3.2.2. A maioria das pessoas que são importantes para o(a) senhor(a), como sua família e amigos, vai cuidar da mata das propriedades delas.

4.3.2.3. A maioria dos líderes religiosos que são importantes para o(a) senhor(a), como padres e pastores, ou líderes de outras religiões, vai cuidar da mata das propriedades deles.

4.3.2.4. A maioria das pessoas que moram perto do(a) senhor(a), como seus vizinhos e pessoas da comunidade ou região, vai cuidar da mata das propriedades delas.

\begin{tabular}{|l|l|l|l|l|l|l|}
1 & 2 & 3 & 4 & 5 & 6 & 7 \\
1 & 2 & 3 & 4 & 5 & 6 & 7 \\
1 & 2 & 3 & 4 & 5 & 6 & 7 \\
1 & 2 & 3 & 4 & 5 & 6 & 7 \\
\hline
\end{tabular}




\begin{tabular}{|c|c|c|c|c|c|c|c|}
\hline $\begin{array}{l}\text { 4.4. Controle comportamental percebido: Pensando agora em coisas que é } \\
\text { preciso ter para poder cuidar da mata desta propriedade no futuro, considerando } \\
\text { os próximos cinco anos, o quanto o(a) senhor(a) concorda com as } \\
\text { frases }\end{array}$ & & $\begin{array}{l}\text { lem } \\
\text { po }\end{array}$ & & & & Mu & \\
\hline 4.4.1. $O(A)$ senhor(a) se sente capaz de cuidar da mata desta propriedade. & 1 & 2 & 3 & 4 & 5 & 6 & 7 \\
\hline $\begin{array}{l}\text { 4.4.2. O(A) senhor(a) tem dinheiro suficiente pra cuidar da mata desta } \\
\text { propriedade. }\end{array}$ & 1 & 2 & 3 & 4 & 5 & 6 & 7 \\
\hline $\begin{array}{l}\text { 4.4.3. O(A) senhor(a) tem os materiais e ferramentas necessários para cuidar da } \\
\text { mata desta propriedade. }\end{array}$ & 1 & 2 & 3 & 4 & 5 & 6 & 7 \\
\hline $\begin{array}{l}\text { 4.4.4. } \mathrm{O}(\mathrm{A}) \text { senhor(a) tem saúde suficiente para cuidar da mata desta } \\
\text { propriedade. }\end{array}$ & 1 & 2 & 3 & 4 & 5 & 6 & 7 \\
\hline $\begin{array}{l}\text { 4.4.5. O(A) senhor(a) tem tempo suficiente para cuidar da mata desta } \\
\text { propriedade. }\end{array}$ & 1 & 2 & 3 & 4 & 5 & 6 & 7 \\
\hline $\begin{array}{l}\text { 4.4.6. Cuidar da mata desta propriedade é uma coisa que depende só do(a) } \\
\text { senhor(a) mesmo(a). }\end{array}$ & 1 & 2 & 3 & 4 & 5 & 6 & 7 \\
\hline
\end{tabular}

4.5. Intenção: Pensando agora no que o(a) senhor(a) pretende fazer na mata desta propriedade pelos próximos cinco anos, o quanto o(a) senhor(a) concorda com as frases

4.5.1. $O(A)$ senhor(a) quer cuidar da mata desta propriedade.

4.5.2. $O(A)$ senhor(a) está desanimado(a) para cuidar da mata desta propriedade.

4.5.3. O(A) senhor(a) tem preguiça de cuidar da mata desta propriedade.

4.5.4. $O(A)$ senhor(a) está fazendo planos para cuidar da mata desta propriedade.

4.5.5. $O(A)$ senhor(a) vai se esforçar para cuidar da mata desta propriedade.

4.5.6. $O(A)$ senhor(a) tem pouca disposição para cuidar da mata desta propriedade.

4.5.7. O(A) senhor(a) se sente motivado(a) para cuidar da mata desta propriedade.

4.5.8. $O(A)$ senhor(a) tem pouco interesse em cuidar da mata desta propriedade
Nem um pouco

Muito

\section{um pouco}

\begin{tabular}{|l|l|l|l|l|l|l|}
1 & 2 & 3 & 4 & 5 & 6 & 7 \\
\hline 7 & 6 & 5 & 4 & 3 & 2 & 1 \\
\hline 7 & 6 & 5 & 4 & 3 & 2 & 1 \\
\hline 1 & 2 & 3 & 4 & 5 & 6 & 7 \\
\hline 1 & 2 & 3 & 4 & 5 & 6 & 7 \\
\hline 7 & 6 & 5 & 4 & 3 & 2 & 1 \\
\hline 1 & 2 & 3 & 4 & 5 & 6 & 7 \\
\hline 7 & 6 & 5 & 4 & 3 & 2 & 1 \\
\hline
\end{tabular}

4.6. Atitude: Gostaria que o(a) senhor(a) me dissesse o que o(a) senhor(a) acha de cuidar da mata desta propriedade pelos próximos cinco anos. Por favor, mostre na escala o quão/quanto (10 extremo) (apontar a bola azul maior) ou (2o extremo) (apontar a bola laranja maior) isso seria.

\begin{tabular}{|l|c|c|c|c|c|c|c|}
\hline 4.6.1. Inútil ou útil & -3 & -2 & -1 & 0 & 1 & 2 & 3 \\
\hline 4.6.2. Desagradável ou agradável & -3 & -2 & -1 & 0 & 1 & 2 & 3 \\
\hline 4.6.3. Chato ou interessante & -3 & -2 & -1 & 0 & 1 & 2 & 3 \\
\hline 4.6.4. Prejudicial ou lucrativo & -3 & -2 & -1 & 0 & 1 & 2 & 3 \\
\hline 4.6.5. Ruim ou bom & -3 & -2 & -1 & 0 & 1 & 2 & 3 \\
\hline 4.6.6. Cansativo ou animador & -3 & -2 & -1 & 0 & 1 & 2 & 3 \\
\hline
\end{tabular}


Nota: Ler ao(à) entrevistado(a) antes de começar as perguntas:

Gostaria de saber também algumas características da mata desta propriedade e com qual frequência o(a) senhor(a) fez as coisas que vou falar a seguir.

\subsection{Cuidados com a mata:}

4.7.1.1. A mata desta propriedade está cercada de todos os lados?

Nota: Se NÃO, ir para a pergunta 9.3.2.1.

$\operatorname{Sim} /$ Não

4.7.1.2. Foi o(a) senhor(a) que colocou a cerca?

Se SIM, faz quantos anos que o(a) senhor(a) colocou a cerca?

anos $\quad$ Sim / Não

4.7.2.1. A mata desta propriedade tem alguma placa ou sinal para evitar que pessoas desconhecidas entrem na mata?

Nota: Se NÃO, ir para a pergunta 9.3.3.

4.7.2.2. Foi o(a) senhor(a) que colocou essa placa ou sinal?

Se SIM, faz quantos anos que o(a) senhor(a) colocou essa placa ou sinal? anos

E no último ano, ou seja, de ___ (preencher com o mês) do ano passado até hoje,

considerando só a mata desta propriedade, com qual frequência o(a) senhor(a) Nunca

Sempre ? Por gentileza, aponte a frequência na escala, desde nunca até sempre.

4.7.3. Deu manutenção na cerca de maneira a evitar que o gado ou pessoas fiquem entrando e andando na mata

4.7.4. Vigiou a mata para não deixar pessoas desconhecidas entrarem e pegarem plantas ou animais da mata

4.7.5. Retirou o lixo encontrado na mata

4.7.6. Fez alguma picada ou trilha na mata por onde poderiam passar muitas pessoas

4.7.7. Usou fogo para limpar o terreno desta propriedade, que poderia incendiar a mata

4.7.8. Cortou árvores, abriu alguma clareira ou pequena estrada na mata

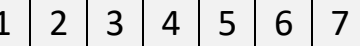

$\begin{array}{llllllllll}1 & 2 & 3 & 4 & 5 & 6 & 7\end{array}$

\begin{tabular}{lllllllll}
1 & 2 & 3 & 4 & 5 & 6 & 7 \\
\hline
\end{tabular}




\section{V - USOS E PREJUÍZOS DA FLORESTA}

Nota: Ler ao(à) entrevistado(a) antes de começar as perguntas:

Para terminar as perguntas sobre a mata, gostaria de saber as coisas que o(a) senhor(a) usou e que vêm da mata, como por exemplo plantas e água, e também sobre coisas que a mata trouxe de bom ou ruim para o(a) senhor(a), como por exemplo uma sensação de alegria ou prejuízos causados por algum animal. Essas coisas podem ser tanto da mata do(a) senhor(a) como de outras matas aqui da região.

\section{Usos e Prejuízos}

Nunca

Sempre

5.1.1. Uso direto consumível: Sobre as coisas que vem da mata e que podemos usar, nesses últimos seis meses, de (preencher com o mês de seis meses atrás) do ano passado até hoje, por favor, mostre na escala com qual frequência o(a) senhor(a) ?

5.1.1.1. Usou água vinda diretamente das minas de nascentes da mata para o(a) senhor(a) e as pessoas que moram nessa casa

5.1.1.2. Usou água vinda diretamente das minas de nascentes da mata para os animais de criação dessa propriedade

5.1.1.3. Usou água vinda diretamente das minas de nascentes da mata para irrigar as plantações dessa propriedade

5.1.1.4. Usou plantas da mata para fazer remédios

5.1.1.5. Usou plantas da mata para enfeitar a sua casa ou sua propriedade

5.1.1.6. Usou algum tipo de comida que vem da mata

5.1.1.7. Usou lenha da mata (podem ser galhos)

5.1.1.8. Usou madeira da mata para construções e cercas

5.1.2. Uso direto não consumível: Vou fazer agora algumas perguntas que tem a ver mais com as emoções que a mata pode trazer, por exemplo, quando vamos passear na mata. Se o(a) senhor(a) costuma ir na mata mais porque precisa fazer alguma coisa lá ou para trabalhar, não tem problema de responder que fez as coisas que vou dizer com pouca frequência. Nesses últimos seis meses, de (preencher com o mês de seis meses atrás) do ano passado até hoje, por favor, mostre na escala com qual frequência o(a) senhor(a) ?

5.1.2.1. Considera que se divertiu na mata

5.1.2.2. Considera que apreciou as plantas e animais da mata

5.1.2.3. Considera que sentiu uma sensação de alegria, paz ou tranquilidade por estar na mata ou observar a mata

5.2. Prejuízos: E sobre as coisas não tão boas que a mata pode trazer, nesses últimos seis meses, de (preencher com o mês de seis meses atrás) do ano passado até hoje, por favor, mostre na escala com qual frequência o(a) senhor(a) ?

5.2.1. Teve problemas com animais da mata que podem ser perigosos, como cobras, aranhas ou vespas

5.2.2. Teve problemas com animais da mata que atacam plantações, como os javalis e maritacas

5.2.3. Teve problemas com animais da mata que atacam animais de criações, como gavião, lagarto, onça, cachorro-do-mato, gambá

5.2.4. Teve que comprar lenha para não usar a lenha da mata

5.2.5. Teve que comprar madeira para não usar a madeira da mata

5.2.6. Teve menos espaço do que gostaria para plantar, criar animais ou construir nesta propriedade por causa da mata

\begin{tabular}{|l|l|l|l|l|l|l|}
1 & 2 & 3 & 4 & 5 & 6 & 7 \\
1 & 2 & 3 & 4 & 5 & 6 & 7 \\
\hline 1 & 2 & 3 & 4 & 5 & 6 & 7
\end{tabular}

\begin{tabular}{|l|l|l|l|l|l|l|}
\hline 1 & 2 & 3 & 4 & 5 & 6 & 7 \\
\hline 1 & 2 & 3 & 4 & 5 & 6 & 7 \\
\hline 1 & 2 & 3 & 4 & 5 & 6 & 7 \\
\hline 1 & 2 & 3 & 4 & 5 & 6 & 7 \\
\hline 1 & 2 & 3 & 4 & 5 & 6 & 7 \\
\hline 1 & 2 & 3 & 4 & 5 & 6 & 7 \\
\hline 1 & 2 & 3 & 4 & 5 & 6 & 7 \\
\hline 1 & 2 & 3 & 4 & 5 & 6 & 7 \\
\hline
\end{tabular}




\section{VI - DADOS SOCIODEMOGRÁFICOS E CARACTERÍSTICAS DA PROPRIEDADE - PARTE II}

Nota: Ler ao(à) entrevistado(a) antes de começar as perguntas:

Já estamos quase acabando, para finalizar, gostaria apenas de saber mais algumas informações sobre o(a) senhor(a) e sua casa.

6.1. Idade: $O(A)$ senhor(a) pode me dizer a data do seu nascimento? Dia I Mês $\mid$ Ano |

6.2. Profissão/atividade: $O(A)$ senhor(a) diria que a sua principal atividade, ou seja, aquela na qual o(a) senhor(a) passa a maior parte do tempo é:

cuidar de plantações ou de animais de criação, ou outras atividades na sua propriedade |

uma atividade na cidade, como trabalhar no comércio ou fazendo algum serviço |

OU

outra |

Qual?

6.3.1. Escolaridade: $O(A)$ senhor(a) já estudou em alguma escola?

$\operatorname{Sim} \mid \_$_ N Não I__ I Nota: Se NÃO, vá para a pergunta 11.4.1.

6.3.2.1. Escolaridade: Até qual série o(a) senhor(a) completou seus estudos? (anotar a série e o nível) série

6.3.2.2. Infantil I__ Fundamental I__ I Médio I__

Nota: Se não completou o MÉDIO vá para a pergunta 11.4.1.

6.3.3.1. Escolaridade: $O(A)$ senhor(a) fez faculdade? Sim I__ $\quad$ Não fez

6.3.3.2. Completa? (anotar sim ou não)

11.3.3.3. Quantos anos?

Nota: Se NÃO ou NÃO COMPLETA, vá para a pergunta 11.4.1.

6.3.4.1. Escolaridade: $O(A)$ senhor(a) fez algum curso de pós-graduação? Sim I Não fez |

6.3.4.2. Completa? (anotar sim ou não)

11.3.4.3. Quantos anos?

Nota: Se NÃO ou NÃO COMPLETA, vá para a pergunta 11.4.1.

6.4.1. Riqueza: Da lista de itens que vou falar a seguir, gostaria que o(a) senhor(a) me dissesse se o(a) senhor(a) ou alguém aqui da sua casa tem alguma destas coisas. Se não tiver, não tem problema.

\begin{tabular}{|l|l|l|l|l|l|}
\hline \multicolumn{1}{|c|}{ Item } & Quant. & \multicolumn{1}{c|}{ Item } & Quant. & \multicolumn{1}{c|}{ Item } & Quant. \\
\hline Trator & & Fogão a gás de 4 bocas & & Telefone fixo & \\
\hline Carroça & & Fogão a gás de 5/6 bocas & & Telefone celular & \\
\hline Carro & Micro-ondas & & Computador & \\
\hline Moto & Tanquinho & & Tablet & \\
\hline Bicicleta & Máquina de lavar roupa & & Ventilador & \\
\hline Gerador de luz & Televisão & & Panela de & \\
\hline Geladeira & DVD & & Liquidificador & \\
\hline Freezer & Aparelho de som & & Batedeira & \\
\hline Forno elétrico & Antena parabólica/satélite & & Banheiros & \\
\hline
\end{tabular}

Nota: Ler ao(à) entrevistado(a) para finalizar:

Gostaríamos de agradecer imensamente pela sua disposição em nos receber e por todas as suas respostas. A sua participação é muito importante para o sucesso desse estudo! 


\section{Appendix D - Scales evaluation and Piecewise SEM implementation}

\section{Evaluating the scales of attitude and intention}

We used three different methods to evaluate the quality of the scales of attitude and intention. To access reliability, the most common metric used is the Cronbach's alpha coefficient $(\alpha)$, based on internal consistency between items (Streiner, 2003). The omega hierarchical coefficient $\left(\omega_{\mathrm{h}}\right)$ is suggested as a reliability measure, when the latent construct has a hierarchical structure (Widhiarso and Ravand, 2014), as in the case of attitude towards a behavior that encompasses both an instrumental and an experiential aspect (Fishbein and Ajzen, 2010). To check construct unidimensionality, we used Confirmatory Factor Analysis (CFA) and its associated fit measures, as the absolute fit indices (e.g., Chi-Squares test) and the relative fit indices (e.g., Comparative Fit Index-CFI; Brown, 2015). In Table D1, we present the different values for the attitude and intention scales, showing that all measures are acceptable considering the cut-off limits.

Table D1: Results from the evaluation of attitude and intention scales.

\begin{tabular}{lccc}
\hline Metric & Cut-off limit $^{\mathrm{a}}$ & Attitude & Intention \\
\hline Cronbach's $\alpha$ & $\geq 0.70$ & 0.89 & 0.81 \\
$\boldsymbol{\omega}_{\mathbf{h}}$ & $\geq 0.70$ & 0.81 & - \\
$\boldsymbol{\chi 2}$ & - & 14.39 & 29.75 \\
$\boldsymbol{d} \boldsymbol{f}$ & - & 9 & 20 \\
p-value & $\geq 0.05$ & 0.11 & 0.07 \\
CFI & $\geq 0.90$ & 0.98 & 0.96 \\
\hline
\end{tabular}

${ }^{a}$ Based on (Widhiarso and Ravand, 2014) and (Olobatuyi, 2006).

\section{Implementing the Piecewise SEM}

We first identified the best distribution for each dependent variable using the function descdist from the fitdistrplus package in R (Delignette-Muller and Dutang, 2017; Figure D1), which indicates distributions in a Cullen and Frey graph based on 
kurtosis and skewness patterns. For the behavioral belif index the best distribution was the lognormal, however, as the glmer function used to construct the models does not support this type of distribution, we used as an alternative the gamma distribution with a $\log$ link function. Furthermore, although the losses/damages and the intention variables fitted a beta distribution, the $\mathrm{R}$ function that models this type of distribution does not support mixed models, so we used instead a gaussian distribution with a logit function that is similar. Transformation of variables were necessary when using the link function $\log$ for the gamma distribution (the minimum possible value plus one was added to all values to achieve only positive values) or logit (all values divided by the maximum possible value to achieve values between 0 and 1), as presented in Table D2.

After specifying the model for de Piecewise SEM it is possible to check its fit through the Fisher's C statistic (Lefcheck, 2016). This statistic is based on the conditional independence and for each independence claim (i.e., all the missing paths in the model) there is a corresponding significance value (i.e., a P-value). Fisher's C combine all P-values for the missing paths. 
A
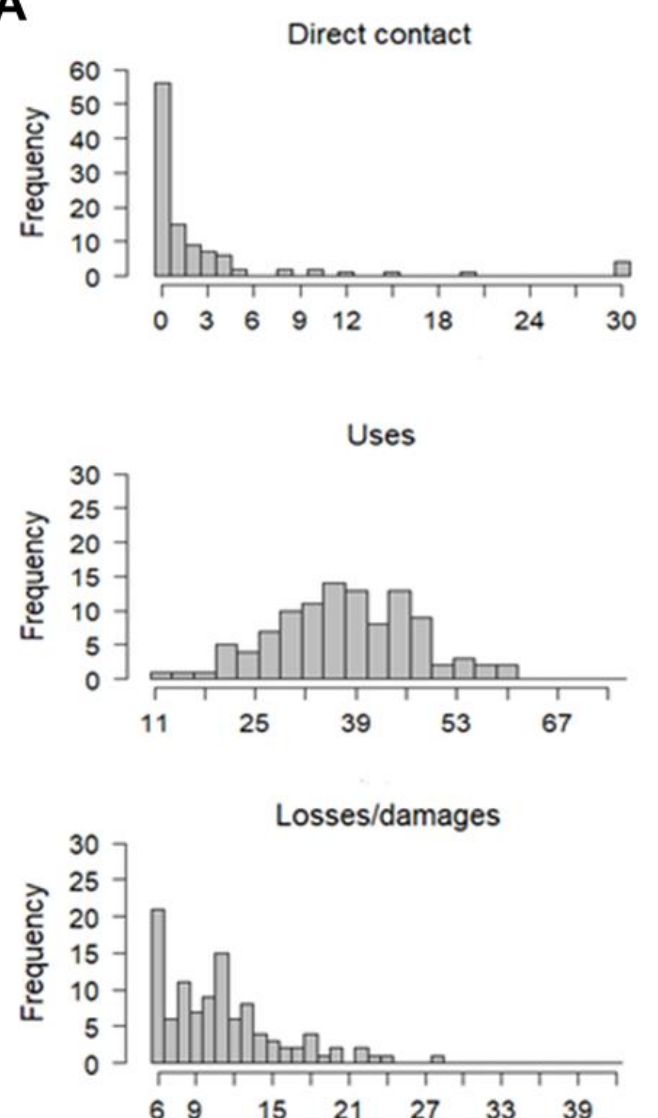

Behavioral beliefs

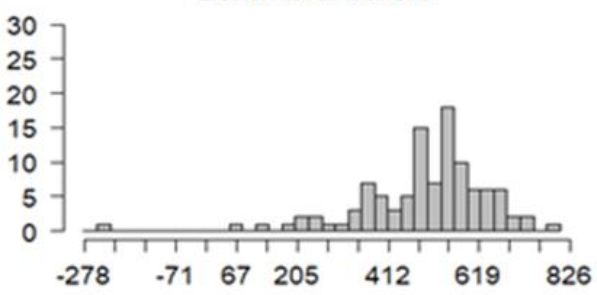

Attitude

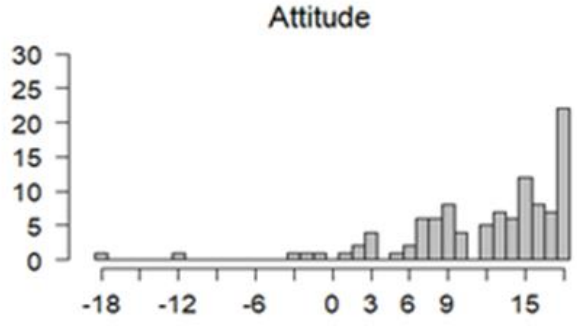

Intention

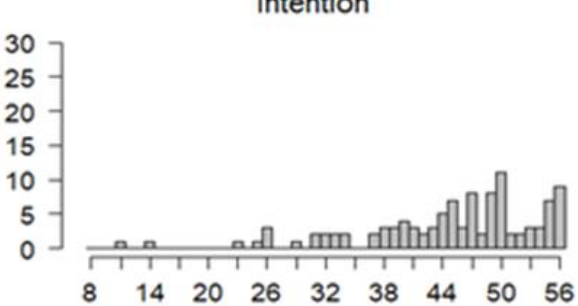

B

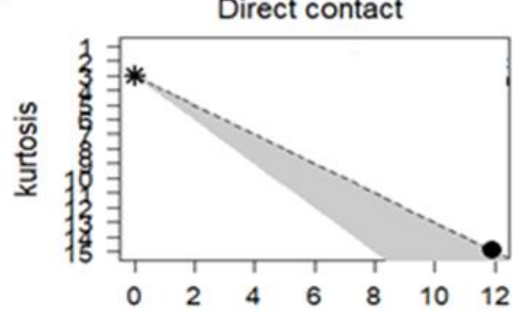

Uses

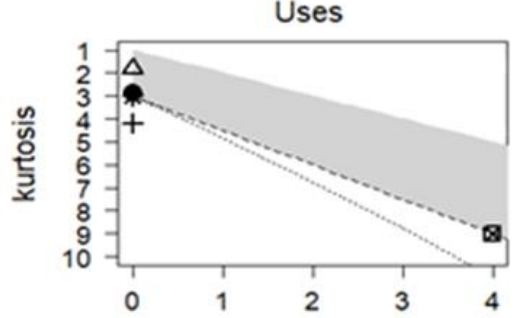

Losses/damages

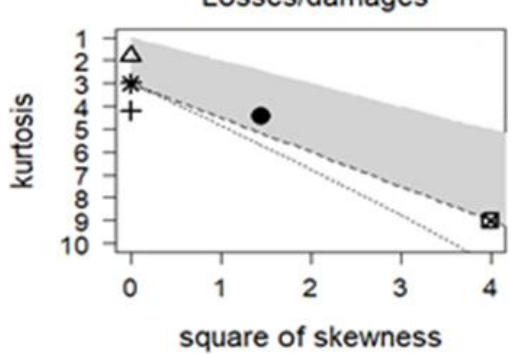

Behavioral beliefs

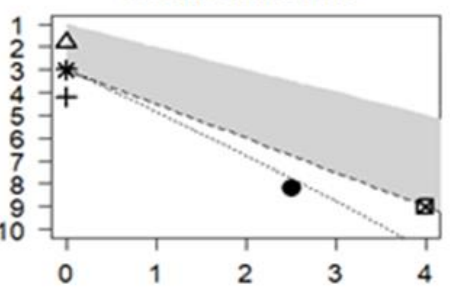

Attitude

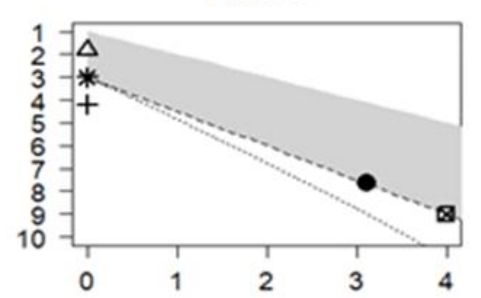

Intention

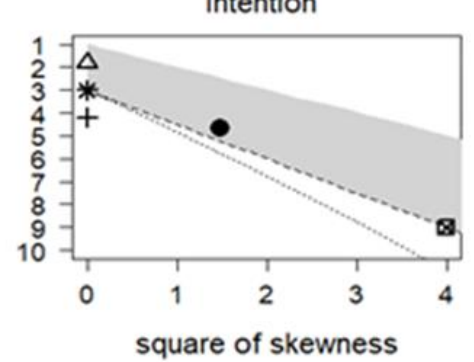

Figure D: Identifying the adequate distribution to model the variables. A - variable histograms. B - Plots of Cullen and Frey graphs using common distributions ( $\Delta$ uniform, * normal, + logistic, - exponential, dashed line - gamma, dotted line - lognormal, grey area - beta, black dot - value for each variable. Direct contact was considered as a discrete variable, so the dashed line represents a poisson distribution. 
Table D2: Distributions, link functions and transformations used to model the variables in the Piecewise-SEM analysis.

\begin{tabular}{|c|c|c|c|c|}
\hline & Variable & $\begin{array}{c}\text { Family } \\
\text { distribution }\end{array}$ & $\begin{array}{c}\text { Link } \\
\text { function }\end{array}$ & Transformation \\
\hline \multirow{3}{*}{$\begin{array}{l}\text { Experiences } \\
\text { with forest }\end{array}$} & Direct contact & poisson & $\log$ & - \\
\hline & Uses & gaussian & identity & \\
\hline & Losses/damages & gaussian & $\operatorname{logit}{ }^{a}$ & $/ 42$ (to range from 0 to 1$)$ \\
\hline \multirow{3}{*}{ Psychological } & $\begin{array}{c}\text { Behavioral } \\
\text { beliefs }\end{array}$ & gamma & $\log$ & +278 (to be positive) \\
\hline & Attitude & gamma & $\log$ & +19 (to be positive) \\
\hline & Intention & gaussian & $\operatorname{logit}{ }^{a}$ & $/ 56$ (to range from 0 to 1$)$ \\
\hline
\end{tabular}

${ }^{\mathrm{a}}$ Using a gaussian distribution with a logit link function is similar to using a beta distribution.

\section{References}

Brown, T.A., 2015. Confirmatory factor analysis for applied research, Second edition. ed, Methodology in the social sciences. The Guilford Press, New York; London.

Delignette-Muller, M.-L., Dutang, C., 2017. Help to Fit of a Parametric Distribution to Non-Censored or Censored Data.

Fishbein, M., Ajzen, I., 2010. Predicting and changing behavior: the reasoned action approach. Psychology Press, New York.

Lefcheck, J.S., 2016. PiecewiseSEM: Piecewise structural equation modelling in R for ecology, evolution, and systematics. Methods in Ecology and Evolution 7, 573-579. https://doi.org/10.1111/2041-210X.12512

Olobatuyi, M.E., 2006. A user's guide to path analysis. University Press of America, Lanham, MD.

Streiner, D.L., 2003. Being Inconsistent About Consistency: When Coefficient Alpha Does and Doesn't Matter. Journal of Personality Assessment 80, 217-222. https://doi.org/10.1207/S15327752JPA8003_01

Widhiarso, W., Ravand, H., 2014. Estimating reliability coefficient for multidimensional measures: A pedagogical illustration. Review of Psychology $21,111-121$. 